This document is confidential and is proprietary to the American Chemical Society and its authors. Do not copy or disclose without written permission. If you have received this item in error, notify the sender and delete all copies.

\title{
Polarized supramolecular aggregates based on luminescent perhalogenated gold derivatives
}

\begin{tabular}{|r|l|}
\hline Journal: & Inorganic Chemistry \\
\hline Manuscript ID & ic-2017-01901u.R2 \\
\hline Manuscript Type: & Article \\
\hline Date Submitted by the Author: & n/a \\
\hline Complete List of Authors: & $\begin{array}{l}\text { Gavara, Raquel; Universitat de Barcelona, Departament de Química } \\
\text { Inorgànica } \\
\text { Pinto, Andrea; Universitat de Barcelona, Departament de Química } \\
\text { Inorgànica i Orgànica } \\
\text { Donamaría, Rocío; Universidad de La Rioja, Departamento de Química } \\
\text { Olmos, María; University of La Rioja, Chemistry } \\
\text { Lopez-De-Luzuriaga, Jose Maria; Complejo Cientifico-Tecnico, } \\
\text { Deptartamento de Quimica (Q.Inorganica) } \\
\text { Rodríguez, Laura; Universitat de Barcelona, İnorganic Chemistry }\end{array}$ \\
\hline
\end{tabular}

SCHOLARONE

Manuscripts 


\title{
Polarized supramolecular aggregates based on luminescent perhalogenated gold derivatives
}

\author{
Raquel Gavara, ${ }^{a}$ Andrea Pinto, ${ }^{a}$ Rocío Donamaría, ${ }^{b}$ M. Elena Olmos, ${ }^{\text {, }}{ }^{*}$ José $\mathrm{M}^{\mathrm{a}}$ López \\ de Luzuriaga, ${ }^{\mathrm{b}}$ Laura Rodríguez, ${ }^{\mathrm{a}, \text {,* }}$ \\ a Departament de Química Inorgànica i Orgànica, Secció de Química Inorgànica, \\ Universitat de Barcelona, Martí i Franquès 1-11, E-08028 Barcelona, Spain. e-mail: \\ laura.rodriguez@qi.ub.es \\ ${ }^{b}$ Departamento de Química, Universidad de la Rioja, Centro de Investigación en \\ Síntesis Química (CISQ), Complejo Científico Tecnológico, 26004-Logroño, Spain. e- \\ mail:m-elena.olmos@unirioja.es \\ ${ }^{c}$ Institut de Nanociència i Nanotecnologia $\left(I^{2}\right.$ UB). Universitat de Barcelona, 08028 \\ Barcelona (Spain)
}

\begin{abstract}
Reaction of $\left[\mathrm{Au}\left(\mathrm{C}_{6} \mathrm{~F}_{5}\right)(\right.$ tht $\left.)\right]$ (tht $=$ tetrahydrothiophene) with 1,3,5-triaza-7phosphaadamantane (PTA) and 3,7-diacetyl-1,3,7-triaza-5-phosphabicyclo[3.3.1]nonane (DAPTA) leads to the formation of $\left[\mathrm{Au}\left(\mathrm{C}_{6} \mathrm{~F}_{5}\right)(\right.$ phosph) (phosph = PTA, $\mathbf{1}$; phosph = DAPTA, 2). The compounds are slightly soluble in water and aggregate at higher concentrations giving rise to the formation of needle- and rod-like structures (1) and well-organized spherical aggregates (2).

Compounds 1 and 2 were reacted with $\mathrm{AgPF}_{6}$ giving rise to the formation in all cases of luminescent water soluble 1:1 $\mathrm{Au} \cdot \mathrm{Ag}$ heterometallic complexes, as evidenced by $\mathrm{X}$-ray crystal structure determination. The use of different silver salts that differ on the counterion induces changes on the resulting luminescence and aggregation morphology.
\end{abstract}

Keywords: gold, silver, aggregation, water, luminescence, X-ray 


\section{Introduction}

One of the main motivating factors that has provoked the rapid development of gold chemistry in the last years has been the characteristic luminescence that many of the gold derivatives show. ${ }^{1}$ Relativistic efects have shown to be of enormous importance to understand the chemical and physical properties of the heaviest $6 \mathrm{~s}$ transition and posttransition metallic elements, mainly gold. ${ }^{1,2}$ Probably, the most important structural consequence of the relativistic effects in gold is the high tendency to form closed-shell interactions between gold(I) centers (called aurophilic interactions) which are commonly responsable of interesting optical properties. ${ }^{3-6}$ These interactions are energetically similar to hydrogen bonds $\left(5-10 \mathrm{kcal} \mathrm{mol}^{7}\right)$. The formation of noncovalent bonding between metals (metallophilic interactions) can also be observed with other metals like silver ${ }^{7}$ and in heterometallic complexes like the formation of $\mathrm{Au} \cdots \mathrm{Ag}$ interactions with similar strength than aurophilic contacts. ${ }^{8}$

Non-covalent interactions, as widely employed in supramolecular chemistry, are increasingly under investigation as a design tool to organize different types of molecules into unique architectures with precisely controlled structures and functions. The resulting structures have recently attracted a significant research interest because they can be used in diverse applications, e.g., in logic gates, molecular machines, switches, and optical-sensors. ${ }^{9}$ In the case of gold(I) complexes, because of the similarity in energy and directionality between aurophilic interactions and hydrogen bonds, aurophilicity plays a key role in the aggregation process in both the solid state and in solution. ${ }^{10}$ These interactions are observed to be the responsible for the formation of very large structures such as gels, fibers, vesicles with intrinsic luminescent properties due to the presence of gold atom. ${ }^{11,12}$

In general, the resulting supramolecular aggregates based on low molecular weight molecules contain, at least, one ligand with a typical moiety known to induce intermolecular assemblies. ${ }^{13}$ Nevertheless, it was recently described by some of us the formation of long and well-organized gold(I) supramolecular structures based on "chemically simple" molecules containing Au(I)-alkynyl units. ${ }^{11,13-15}$ The intermolecular assemblies are based on aurophilic contacts together with hydrogen bonds and $\pi-\pi$ stacking. ${ }^{16}$ Aurophilic-induced aggregates are also found for $\mathrm{RAu}-\mathrm{C}_{6} \mathrm{~F}_{5}$ derivatives for $\left[\left(\mathrm{C}_{6} \mathrm{~F}_{5} \mathrm{Au}\right)(\mu-1\right.$-(decyloxy)-4-isocyanophenyl $\left.)\right]{ }^{17} \quad\left[\left(\mathrm{C}_{6} \mathrm{~F}_{5} \mathrm{Au}\right)_{2}(\mu-1,4-\right.$ diisocyanobenzene $)],{ }^{18}\left[\left(\mathrm{C}_{6} \mathrm{~F}_{5} \mathrm{Au}\right)\left(\mathrm{CNC}_{6} \mathrm{H}_{4} \mathrm{O}(\mathrm{O}) \mathrm{CC}_{6} \mathrm{H}_{4} \mathrm{OC}_{10} \mathrm{H}_{21}\right] .{ }^{19}\right.$ But, to the best of 
our knowledge, there is no precedent in the literature about low molecular weight gold(I) supramolecular aggregates in water based on $\mathrm{Au}-\mathrm{C}_{6} \mathrm{~F}_{5}$ discrete molecules without any common ligand expected to induce aggregation. ${ }^{20}$

Water is the ideal solvent for synthetic processes from an economical and ecological industrial point of view. However, the use of water as solvent requires the synthesis of reagents stable and soluble in this medium. One of the most common strategies for solubilising metallic derivatives in water involves the use of ligands with hydrophilic properties. Regarding gold(I) complexes, phosphane ligands are commonly used due to the stability of the Au-P bond. Among the many water-soluble phosphanes currently available, the adamantane-like phosphane 1,3,5-triaza-7-phosphaadamantane (PTA) and its derivatives have received special attention owing to its similar reactivity to other alkylphosphanes and its higher air stability and resistance to oxidation than other watersoluble phosphanes. ${ }^{21}$

Taking all of this into consideration, in this work we have introduced water soluble phosphanes (PTA and 3,7-diacetyl-1,3,7-triaza-5-phosphabicyclo[3.3.1]nonane, DAPTA) as a second coordination position of a Au- $\mathrm{C}_{6} \mathrm{~F}_{5}$ moiety in order to obtain organometallic perhalogenated gold(I) systems with increasing solubility in water. The reaction of the gold(I) complexes with different silver salts has given rise to the formation of heterometallic systems that display different supramolecular structures in water and intrinsic luminescence that depends on the counterion. Moreover, the resulting aggregates present a particular alignment that depends on the polarization angle, comparable to the behavior presented by lyotropic chromonic liquid crystals (LCLCs). 


\section{Results and Discussion}

\section{Synthesis and Characterization}

$\left[\mathrm{Au}\left(\mathrm{C}_{6} \mathrm{~F}_{5}\right)(\mathrm{PTA})\right]^{22}(\mathbf{1})$ and $\left[\mathrm{Au}\left(\mathrm{C}_{6} \mathrm{~F}_{5}\right)(\mathrm{DAPTA})\right](\mathbf{2})$ were obtained by the reaction of $\left[\mathrm{Au}\left(\mathrm{C}_{6} \mathrm{~F}_{5}\right)\right.$ (tht) $]$ (tht $=$ tetrahydrothiophene) with an equimolecular amount of the corresponding phosphane in dichloromethane by direct displacement of the labile tht ligand and coordination of the phosphorus atom to gold (Scheme 1).

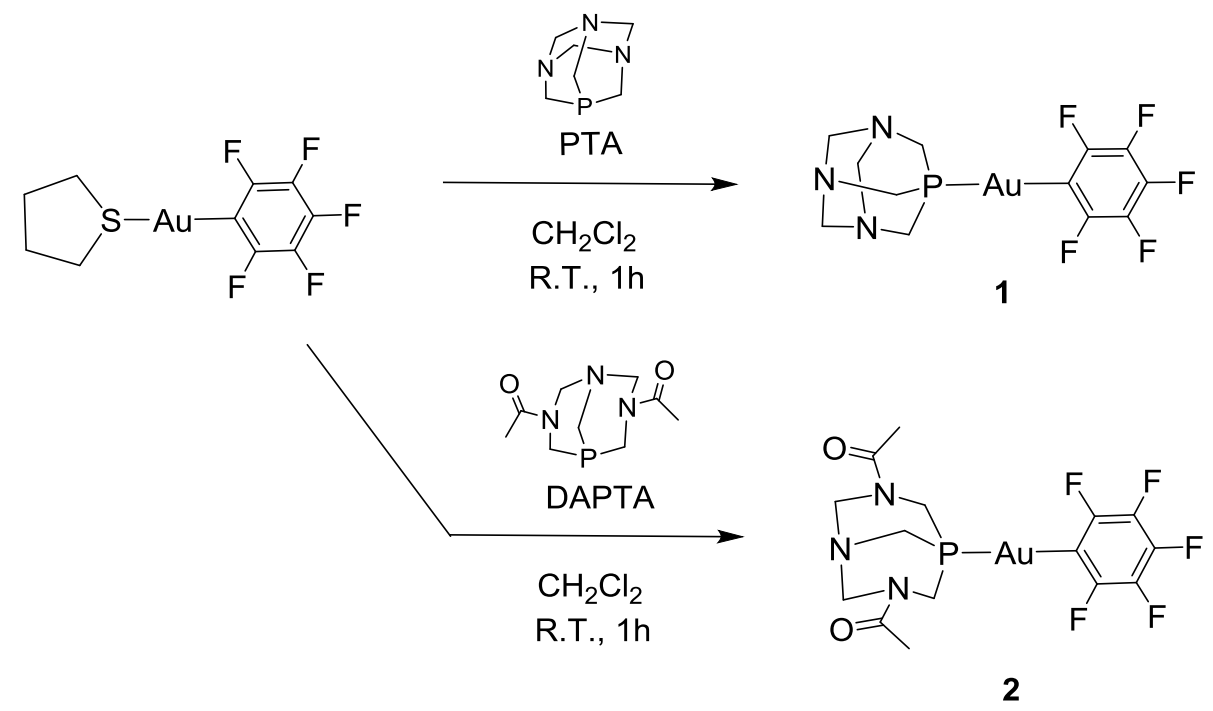

Scheme 1. Synthesis of complexes 1 and $\mathbf{2}$.

Both complexes were obtained as white solids stable to air and moisture. Their elemental analyses and spectroscopic data are in accordance with the proposed stoichiometries (see Experimental Section). Their mass spectra show peaks at $\mathrm{m} / \mathrm{z}$ 522.04 and 594.07 corresponding to $\left[\mathrm{Au}\left(\mathrm{C}_{6} \mathrm{~F}_{5}\right)(\mathrm{PTA})\right]+\mathrm{H}^{+}$and $\left[\mathrm{Au}\left(\mathrm{C}_{6} \mathrm{~F}_{5}\right)(\mathrm{DAPTA})\right]+$ $\mathrm{H}^{+}$. Their IR spectra show signals corresponding to the fragment $\left[\mathrm{Au}\left(\mathrm{C}_{6} \mathrm{~F}_{5}\right)\right]$ at $c a$. 1505,960 , and $760 \mathrm{~cm}^{-1}$, together with the $\mathrm{CH}_{2}$ vibrations of the phosphanes and the $\mathrm{C}=\mathrm{O}$ strong band in the case of $\mathbf{2}$.

Their ${ }^{19}$ F-NMR spectra in deuterated acetone display the three non-equivalent fluorine atoms at -116.7 (ortho), -160.8 (para), -164.1 (meta) and very similar signals for 2 (see SI), in accordance with the chemical shift of $\mathrm{Au}^{\mathrm{I}}-\mathrm{C}_{6} \mathrm{~F}_{5}$ complexes. Their ${ }^{31} \mathrm{P}-\mathrm{NMR}$ spectra show only one signal at $c a$. -46.8 and -18.3 ppm for $\mathbf{1}$ and 2, respectively, shifted from those of the free ligands, confirming their coordination to the gold centers. Finally, their ${ }^{1} \mathrm{H}$-NMR spectra display the typical pattern of the PTA and DAPTA phosphanes (see SI). 
Once the gold(I) derivatives were obtained and characterized, $\mathrm{AgPF}_{6}$ was added to independent acetonitrile solutions of $\mathbf{1}$ and $\mathbf{2}$ in order to obtain the corresponding heterometallic complexes (Scheme 2).

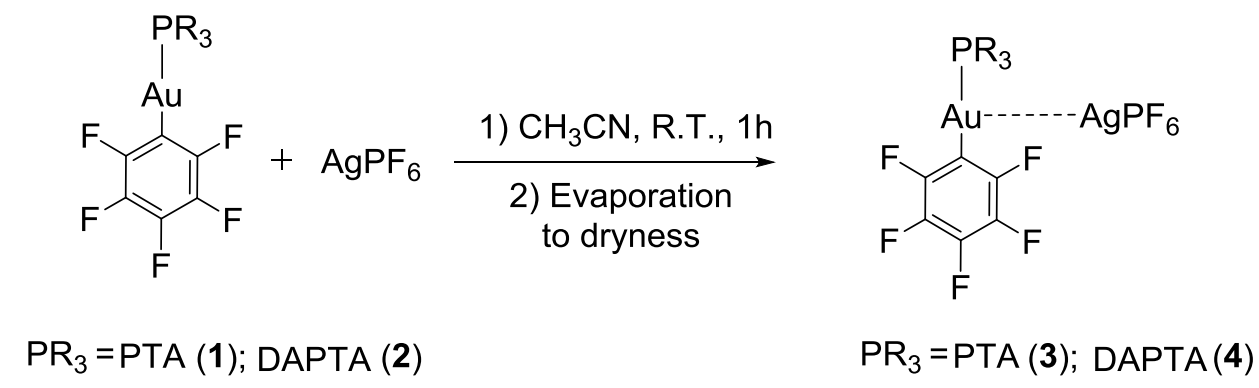

Scheme 2. Synthesis of $\mathrm{Au} \cdot \mathrm{Ag}$ heterometallic complexes. The coordination mode of the atoms of $\mathbf{1} / \mathbf{2}$ with the silver cation in the resulting complex is not determined in this scheme.

Attempts to obtain heterometallic complexes with different stoichiometries (Au:Ag 1:1, $1: 2$ and 1:3) were performed by the addition of 1,2 and 3 equivalents of the silver salt in the acetonitrile solution reaction. In the case of $\mathbf{1},{ }^{1} \mathrm{H}-\mathrm{NMR}$ titration data indicate a progressive shift of the signals (intermediate complexes) with increasing amounts of the silver salt (Figure 1), while similar experiments with complex 2 lead directly to the formation of the same final product in all cases (Figure S9). The analysis of the data seems to indicate that in both cases the addition of increasing amounts of $\mathrm{Ag}^{+}$gives rise to the formation of the analogous product, which does not depend on the stoichiometry of the reaction (gold complex:silver salt). The chemical shifts' changes indicate that the formation of the DAPTA derivative is kinetically faster. On the other hand, PTA protons display larger downfield shifts in the coordination with $\mathrm{Ag}^{+}$than DAPTA signals. This is an indication of a different coordination mode of the silver cation in the formation of the heterometallic complexes 3 and 4. The presence of acetonitrile molecules are observed in all cases, being indicative of the coordination of this solvent probably for the stabilization of the resulting structures (Figures 1 and S9 below). 


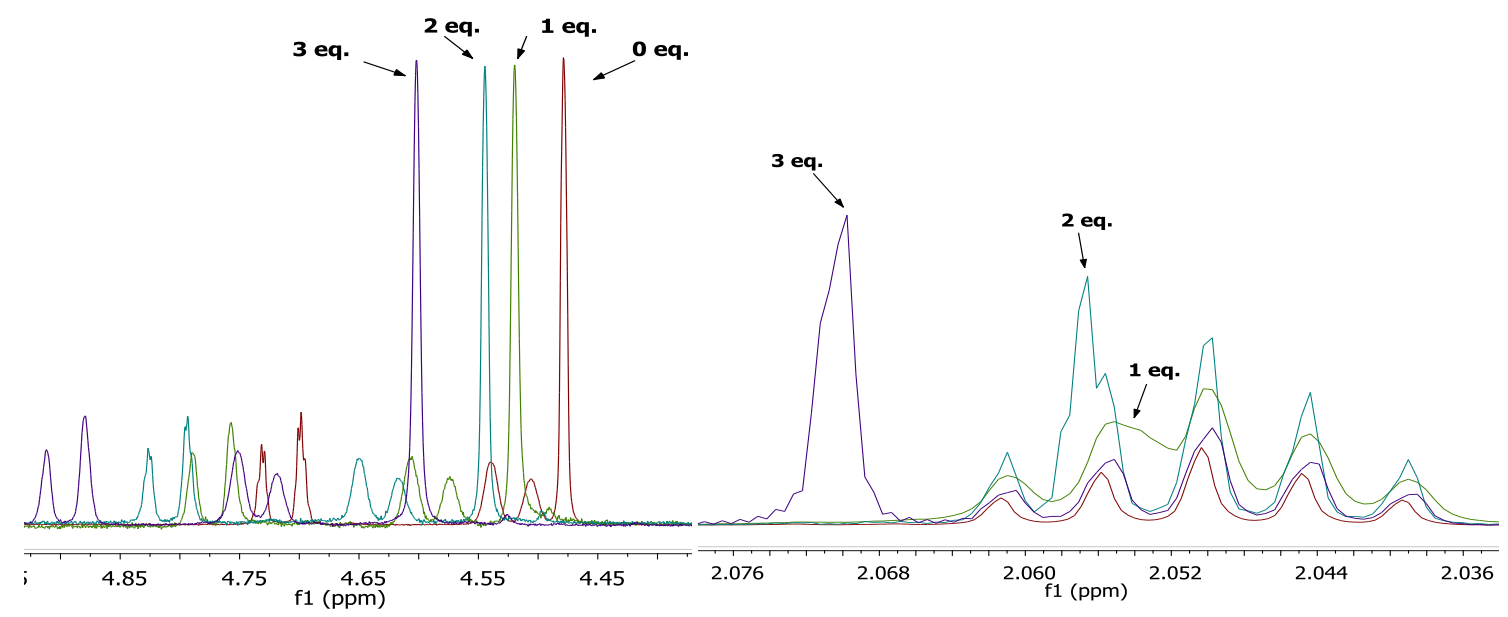

Figure 1. ${ }^{1} \mathrm{H}-\mathrm{NMR}$ spectra of $\mathbf{1}$ with increasing amounts of $\mathrm{AgPF}_{6}$ salt. Phosphane region (left) and acetonitrile peak (overlapped with acetone- $d_{6}$, right) in acetone- $d_{6}$.

Their ${ }^{19} \mathrm{~F}$ - and ${ }^{31} \mathrm{P}-\mathrm{NMR}$ spectra follow the same trend (see SI). The formation of the heterometallic species was definitively confirmed by ESI-MS spectrometry, where the presence of $\mathrm{Au} \cdots \mathrm{Ag}$ complexes are clearly detected in all cases (Figure 3 and S12), being indicative of the stability of this metallophilic interaction in solution. The presence of acetonitrile molecules within the heterometallic structure is also evidenced in their ESI-MS spectra, as previously observed in their ${ }^{1} \mathrm{H}-\mathrm{NMR}$ ones.

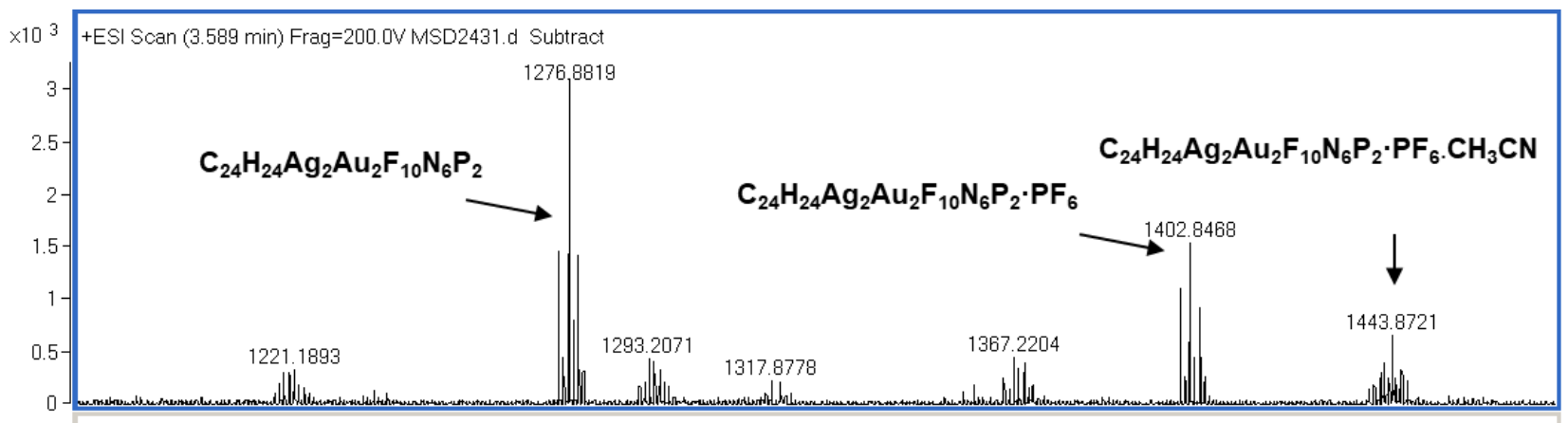

Figure 3. ESI-MS spectrum of $1 \cdot \operatorname{AgPF}_{6}(3)$. 


\section{X-ray Crystal Structural Determination}

Single crystals of the monometallic complexes $\mathbf{1}$ and $\mathbf{2}$ suitable for X-ray diffraction were grown from dichloromethane/hexane solutions. They crystallize in the $\mathrm{C} 2 / \mathrm{c}$ and $\mathrm{P} 2{ }_{1} / \mathrm{c}$ space groups of the monoclinic system, respectively, and complex $\mathbf{2}$ crystallizes with half a molecule of water per molecule of compound. Selected bond lengths and angles are summarized in Table S1 and details of data collection, and refinement in Table S2.

Both crystal structures consist of linear $\left[(\operatorname{aryl}) \mathrm{Au}\left(\mathrm{PR}_{3}\right)\right]$ molecules, which in the case of complex 1 are associated in pairs via aurophilic interactions of 3.1173(4) $\AA$ (Figure 4 and S13). The aurophilic interaction observed in $\mathbf{1}$ is shorter than those reported for related gold(I) derivatives with PTA, ${ }^{23-27}$ which vary from $3.1388(11) \AA$ in $[\mathrm{Au}\{\mathrm{C} \equiv \mathrm{C}-$ $\mathrm{C}(\mathrm{Me})(\mathrm{Et}) \mathrm{OH}\}(\mathrm{PTA})]^{27}$ and $3.457(1) \AA$ in $\left[\mathrm{Au}(\mathrm{PTA})_{2}\right]\left[\mathrm{Au}\left(\mathrm{CN}_{2}\right)\right],{ }^{24}$ or than in $[\mathrm{Au}\{7-$

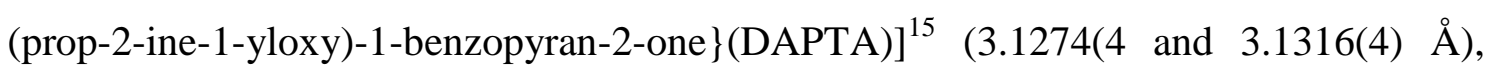
and it is only longer than in $\left[\mathrm{Au}\left(\left\{\mathrm{SPh}\left(3,5-\mathrm{Cl}_{2}\right)\right\}(\mathrm{PTA})\right],{ }^{24}\right.$ which displays a $\mathrm{Au}-\mathrm{Au}$ distance of 3.0468(10) $\AA$. The Au-P distances and Au-C are similar to other reported $\mathrm{Au}(\mathrm{I})-\mathrm{PTA}^{15,24-26}$ and $\mathrm{Au}(\mathrm{I})-\mathrm{C}_{6} \mathrm{~F}_{5}{ }^{27-30}$ complexes. Their $\mathrm{C}-\mathrm{Au}-\mathrm{P}$ angles of $169.3(1)^{\mathrm{o}}$ and $174.7(3)^{\circ}$ for $\mathbf{1}$ and $\mathbf{2}$, respectively, indicate some deviation from the usual linear geometry, as reported for analogous complexes. ${ }^{15,24}$ In the case of complex $\mathbf{1}$, this fact is probably caused by the aurophilic interaction.
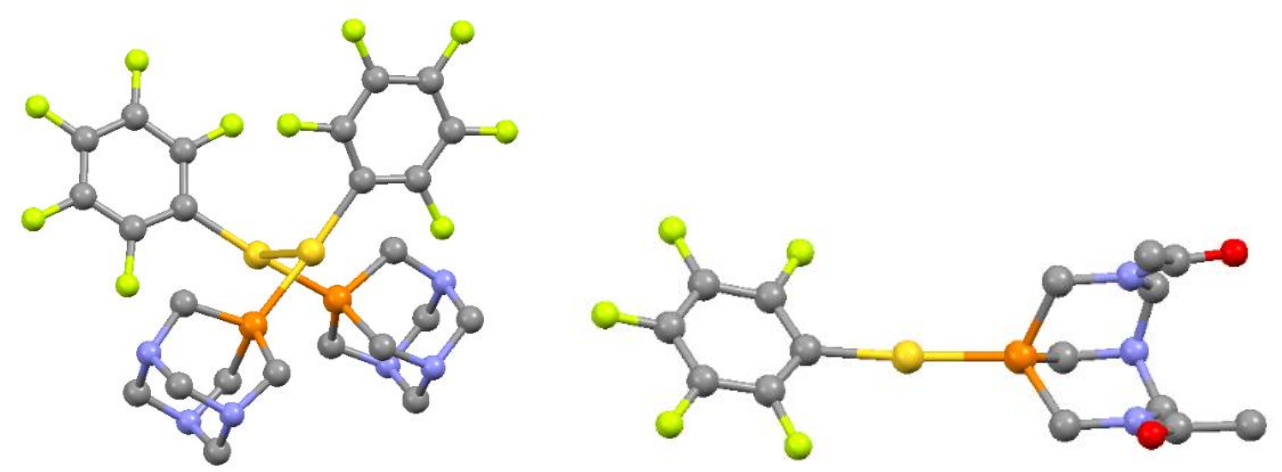

Figure 4. Molecular structure of 1 (left) and $2 \cdot 0.5 \mathrm{H}_{2} \mathrm{O}$ (right). Yellow: gold; orange: phosphorus; grey: carbon; light blue: nitrogen; red: oxygen and green: fluorine. Hydrogens are omitted for clarity. 
The two assembled molecules in $\mathbf{1}$ are twisted in an orthogonal fashion to avoid steric hindrance with torsion angles $82.81^{\circ}$ [C1-Au1-Au2-C2], and are extended in the 3D crystal packing (Figure S14). These $\mathrm{Au} \cdots \mathrm{Au}$ interactions are not present in the analogous complex containing a phenyl instead of pentafluorophenyl group. ${ }^{26}$ The resulting packing in $\mathbf{1}$ presents a zig-zag orientation, as depicted in Figure 5, where $\mathrm{Au} \cdots \mathrm{Au}$ contacts are maintained forming dimers that produce the resulting zig-zag structure (Figure S15).

In the case of $2 \cdot 0.5 \mathrm{H}_{2} \mathrm{O}$, no aurophilic contacts are present, with $\mathrm{Au} \cdots \mathrm{Au}$ distances longer than $6 \AA$. Interestingly, an unusual $\mathrm{C}-\mathrm{H} \cdots \mathrm{Au}$ hydrogen bond, with a gold atom as acceptor, is observed $\left(\mathrm{H} \cdots \mathrm{Au}=2.833(1) \AA, \mathrm{C} \cdots \mathrm{Au}=3.657(14) \AA, \mathrm{C}-\mathrm{H} \cdots \mathrm{Au}=144.4^{\circ}\right)$. A series of additional $\mathrm{O}-\mathrm{H} \cdots \mathrm{O}, \mathrm{C}-\mathrm{H} \cdots \mathrm{O}$ and $\mathrm{C}-\mathrm{H} \cdots$ hydrogen bonds gives rise to a $2 \mathrm{D}$ network (see Table S3 and Figure S16).

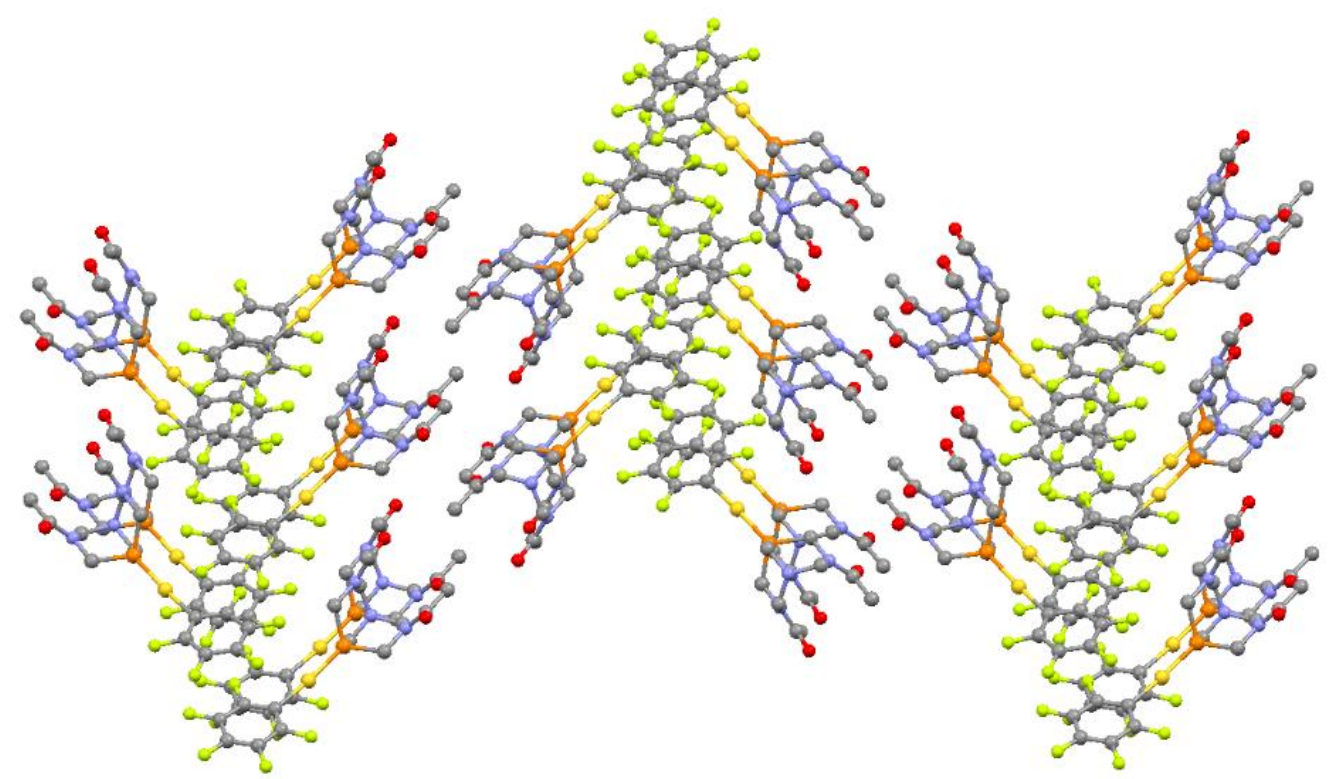

Figure 5. Crystal packing representation of $\mathbf{2} \cdot 0.5 \mathrm{H}_{2} \mathrm{O}$ (right). Yellow: gold; orange: phosphorus; grey: carbon; light blue: nitrogen; red: oxygen and green: fluorine.

Hydrogens are omitted for clarity.

The nature and geometry of the heterometallic complexes could also be verified by Xray crystal diffraction. Single crystals suitable for X-ray diffraction were grown successfully for 4 synthesized in Au:Ag 1:1 and 1:2 stoichiometry, both of them giving rise to identical structures (1:1 complex, Tables S4-S5). Complex 4 crystallizes with an acetonitrile, an acetone and half a water molecule per molecule of compound. The Xray crystal structure of $4 \cdot \mathrm{NCMe} \cdot \mathrm{Me}_{2} \mathrm{CO} \cdot 0.5 \mathrm{H}_{2} \mathrm{O}$ shows heterodinuclear units displaying 
strong $\mathrm{Au} \cdots \mathrm{Ag}$ contacts of 2.8160(12) $\AA$, and tetranuclear dications are further formed thanks to the presence of O-bridging atoms of the phosphanes (Figure 6, S17 and Table $\mathrm{S} 4)$. The $\mathrm{Au} \cdots \mathrm{Ag}$ distances are similar to those previously reported for $\mathrm{Au} / \mathrm{Ag}$ heterometallic complexes containing the unit $\mathrm{Au}-\mathrm{C}_{6} \mathrm{~F}_{5} \quad\left(\left[\mathrm{Ag}_{2} \mathrm{Au}_{2}\left\{4-\mathrm{C}_{6} \mathrm{~F}_{4}(4-\right.\right.\right.$ $\left.\left.\left.\mathrm{C}_{6} \mathrm{BrF}_{4}\right)\right\}_{2}\left(\mathrm{CF}_{3} \mathrm{CO}_{2}\right)_{2}(\mu-\mathrm{L}-\mathrm{L})\right]_{\mathrm{n}}$, with $\mathrm{L}-\mathrm{L}=\mathrm{dppm}$ and dppb ${ }^{31}$ and shorter than in other polymeric $\mathrm{Au} / \mathrm{Ag}$ structures. ${ }^{32-34}$ The gold centers display their usual linear environment, if the metal-metal contacts are not taken into account, with typical Au-P and $\mathrm{Au}-\mathrm{C}$ bond lengths. The silver atoms display a distorted tetrahedral geometry by coordination to the gold center, to the nitrogen atom of an acetonitrile molecule, to the oxygen of an acetone crystallization molecule and to a bridging oxygen atom of the phosphane. Consequently, this last Ag-O bond distance (2.416(13) $\AA$ ) is longer than other one $(2.293(10) \AA)$. The presence of additional $\mathrm{O}-\mathrm{H} \cdots \mathrm{O}, \mathrm{O}-\mathrm{H} \cdots \mathrm{N}$ and $\mathrm{C}-\mathrm{H} \cdots \mathrm{O}$ hydrogen bonds results in a one-dimensional polymer (Figure S17 and Table S6).

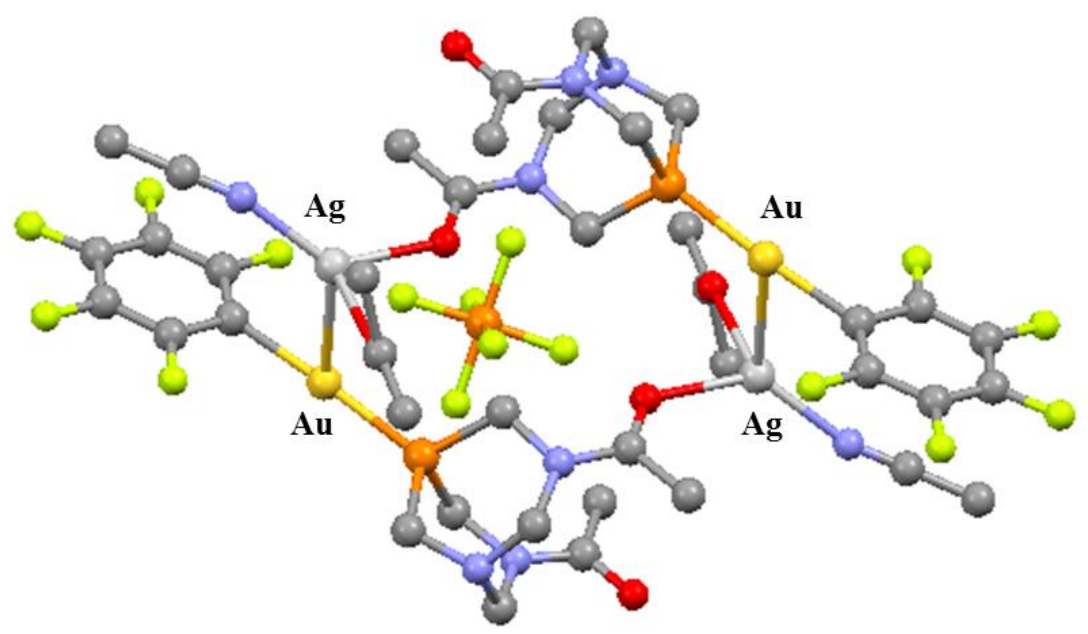

Figure 6. X-ray crystal representation of the dimeric units shown in 4. $\mathrm{NCMe} \cdot \mathrm{Me}_{2} \mathrm{CO} \cdot 0.5 \mathrm{H}_{2} \mathrm{O}$. Yellow: gold; blue: silver; orange: phosphorus; grey: carbon; light blue: nitrogen; red: oxygen and green: fluorine. Hydrogens are omitted for clarity.

Unfortunately, we were not able to grow single crystals of complex $\mathbf{3}$ suitable for X-ray diffraction studies. Nevertheless, the larger downfield shifts in the phosphane protons in the ${ }^{1} \mathrm{H}-\mathrm{NMR}$ spectrum of complex 3 with respect to that of $\mathbf{4}$ (upon coordination with silver cation), makes us expect a shorter metallophilic $\mathrm{Au} \cdots \mathrm{Ag}$ contact in this case, what would get the silver centers closer to the phosphane in $\mathbf{3}$ than in $\mathbf{4}$. 


\section{Photophysical characterization}

Absorption and emission spectra of all complexes were recorded in water at concentration $c a \cdot 10^{-4} \mathrm{M}$, and the results are summarized in Table 1 and Figure 7.

Table 1. Absorption and emission data of compounds 1-4. Emission spectra were recorded upon excitation at $375 \mathrm{~nm}$.

\begin{tabular}{cccc}
\hline Compound & $\begin{array}{c}\text { Absorption } \\
\lambda_{\text {max }}(\mathbf{n m})\end{array}$ & $\begin{array}{c}\text { Emission } \\
(\text { solution, }\end{array}$ & $\begin{array}{c}\text { Emission } \\
(\text { solid, } \\
\left.\lambda_{\max }(\mathbf{n m})\right)\end{array}$ \\
\hline $\left.\mathbf{( \varepsilon}\left(\mathbf{M}^{-\mathbf{1}} \mathbf{c m}^{-\mathbf{1}}\right)\right)$ & $\left.\lambda_{\max }(\mathbf{n m})\right)$ & \\
\hline $\mathbf{1}$ & 255 & - & 487 \\
& $(5861)$ & & 474 \\
$\mathbf{3}$ & 253 & & 541 \\
& $(4850)$ & 530 & 547 \\
$\mathbf{4}$ & 255 & & \\
& $(9868)$ & 530,649 & \\
& 253 & & \\
& $(5000)$ & & \\
\end{tabular}
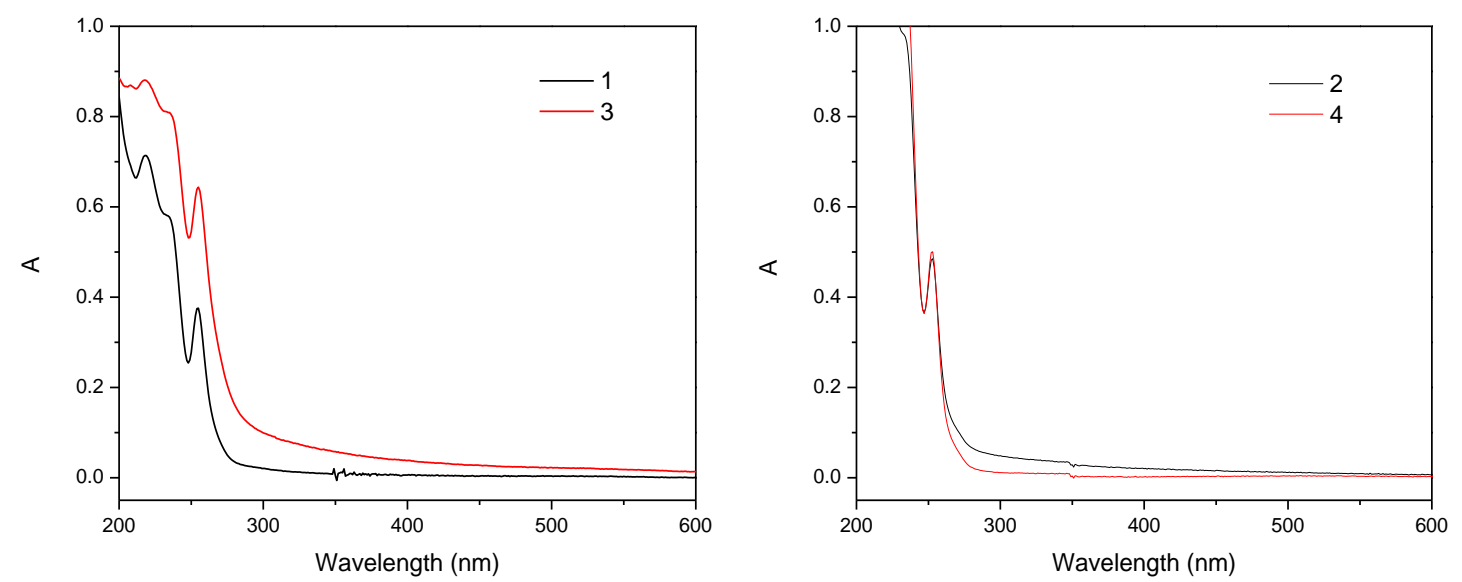

Figure 7. Absorption spectra of complexes 1-4 in water at concentration $6.5 \cdot 10^{-5} \mathrm{M}(\mathbf{1}$ and $\mathbf{3})$ or $1 \cdot 10^{-4} \mathrm{M}(\mathbf{2}$ and $\mathbf{4})$.

The absorption profiles display the typical $\pi-\pi^{*}$ intraligand transition of the pentafluorphenyl unit around $250 \mathrm{~nm}$, together with $\sigma \rightarrow a_{\pi}$ transitions associated with 
coordinated phosphanes at higher wavelengths. Absorption spectra of the gold complexes 1 and 2 display an additional tail at $c a .300 \mathrm{~nm}$, which can be assigned to the presence of aurophilic interactions ( $\sigma^{*} \mathrm{Au}-\mathrm{Au} \rightarrow \pi^{*}$ transition) in solution. ${ }^{16,35}$ In fact, these bands at longer wavelength are better observed at higher concentrations, indicating that the $\mathrm{Au} \cdots \mathrm{Ag}$ interactions are more favored with increasing concentrations.

For the PTA derivatives, extinction coefficient of the heterometallic complex (Table 1) is higher than the corresponding gold(I) precursor, what can be due to an increase of the solubility when the charged heterometallic complex is formed. This fact was also observed with other $\mathrm{Au} / \mathrm{Ag}$ systems with similar aromatic rings and containing phosphanes as the secondary ancillary ligand. ${ }^{30}$

Only the heterometallic complexes show luminescence in aqueous solution showing emission peaks at $c a .530$ and $650 \mathrm{~nm}$ that may have their origin on aggregates in solution, according to the excitation spectra (Figure S18). By contrast, strong luminescence is observed for all compounds in solid state upon excitation of the samples at ca. $375 \mathrm{~nm}$ (Figure 8 and S19).
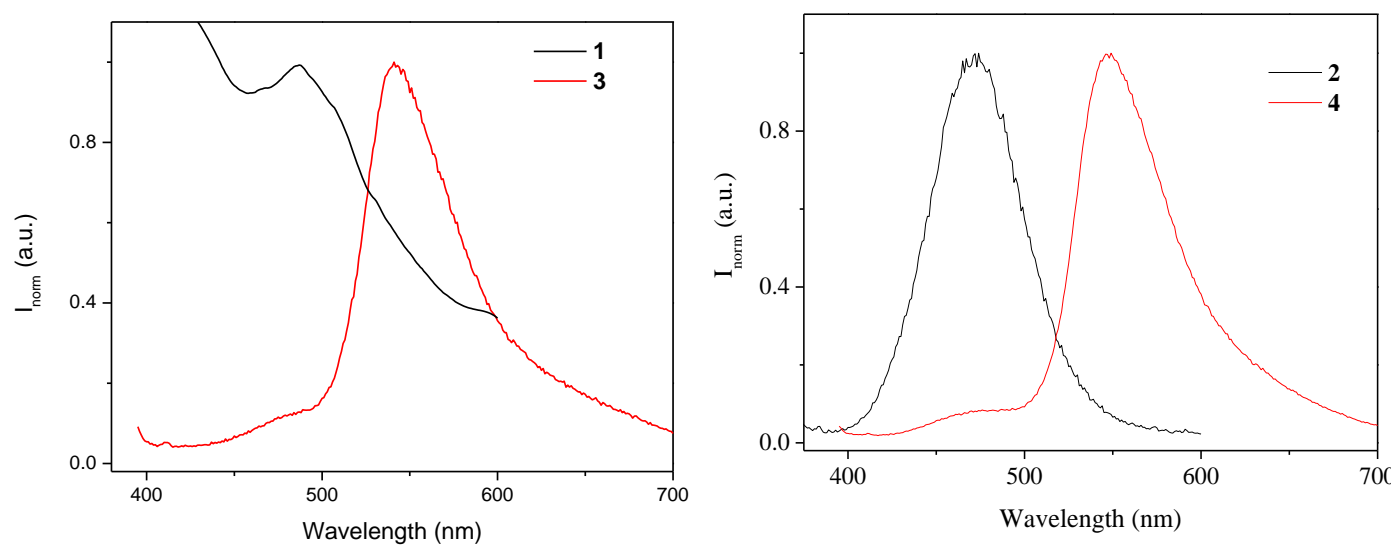

Figure 8. Normalized emission spectra of compounds 1-4 upon excitation solids at 375 nm.

The same emission was observed when the synthesis was carried out with 1, 2 and 3 equivalents of $\mathrm{AgPF}_{6}$, which is an additional evidence of the same resulting heterometallic 1:1 complexes (Figure S20).

It can be observed that the gold complexes $\mathbf{1}$ and $\mathbf{2}$ display a broad emission band at $c a$. $480 \mathrm{~nm}$, which is approximately $70 \mathrm{~nm}$ red-shifted in the resulting heterometallic structures 3 and 4 . The energies of these bands are in the same range as those previously 
described for (terpy) $\mathrm{AuC}_{6} \mathrm{~F}_{5}$ complexes $^{30}$ and heterometallic $\mathrm{Au}-\mathrm{Ag}$ structures, containing $\mathrm{Au} \cdots \mathrm{Ag}$ interactions. ${ }^{36}$ The observed emission bands in complexes $\mathbf{1}$ and $\mathbf{2}$ may arise from ${ }^{3}$ MLCT transitions (gold to perfluoroaryl ligand charge transfer), although a $\pi-\pi$ excimeric ${ }^{3} \mathrm{IL}$ emission cannot be ruled out because of the possible $\pi-\pi$ stacking of the aromatic ligands in the solid state. In the case of $\mathbf{3}$ and $\mathbf{4}$, and taking into consideration the observed red shift, the resulting emissions are likely to arise from ligand to metal-metal (Au- Ag) to ligand charge transfer $\left({ }^{3} \mathrm{MMLCT}\right) .{ }^{36}$ The triplet assignment of these bands is due to the large Stokes' shift observed in all cases.

\section{Aggregation in water}

The presence of PTA and DAPTA phosphanes together with fluorine atoms (able to be involved on hydrogen bonds) and gold/silver metal atoms (able to establish metallophilic interactions) makes us to expect possible formation of supramolecular aggregates, as previously observed with other organometallic PTA and DAPTA organometallic gold(I) complexes. ${ }^{11,13-15,37}$

Absorption spectra variations recorded at different concentrations are not linear in all cases, in agreement with aggregation effect ${ }^{38}$ (Figure 9 and S21-S23), and indicate very low critical aggregation concentration (CAC) values: $5 \cdot 10^{-5} \mathrm{M}$ for gold(I) complexes and slightly higher $\left(1 \cdot 10^{-4}\right.$ and $\left.7 \cdot 10^{-5} \mathrm{M}\right)$ for $\mathbf{3}$ and $\mathbf{4}$, respectively.

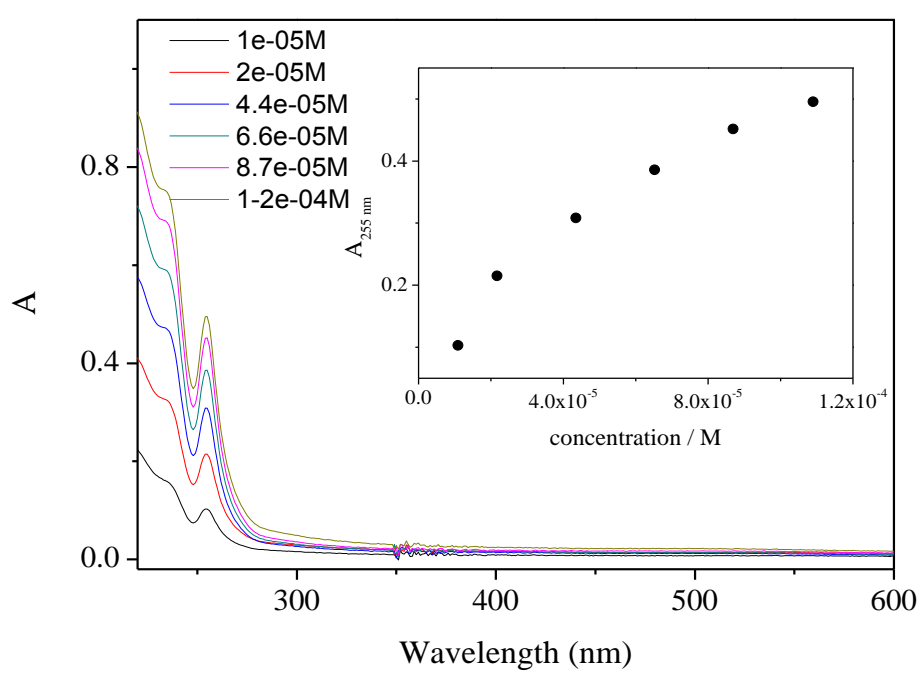

Figure 9. Absorption spectra of $\mathbf{1}$ at different concentrations in water. Inset:

Representation of absorption at $255 \mathrm{~nm}$ versus concentration. 
Emission spectra of the heterometallic complexes recorded at different concentrations follow the same trend, with a deviation of the linearity of the emission maxima with increasing concentrations (Figures S24-S25) at similar CAC value.

The formation of large and well-organized supramolecular aggregates was also evidenced by microscopic techniques. Optical microscopy images of 1-4 under polarized light are displayed in Figure 10 and show different type of morphologies: from needle- and rod-like structures in compound 1, spherical aggregates in $\mathbf{2}$ and dendritic and higher entangled agglomerates in the case of the heterometallic complexes (evidenced by the spherulite profile seen under polarized light). ${ }^{39,40}$ That means that the establishment of $\mathrm{Au} \cdots \mathrm{Ag}$ contacts favors the global contacts and gives rise to larger structures. As previously observed for gold(I) water soluble complexes in water, the size of the aggregates increases with time as shown in Figure S26.

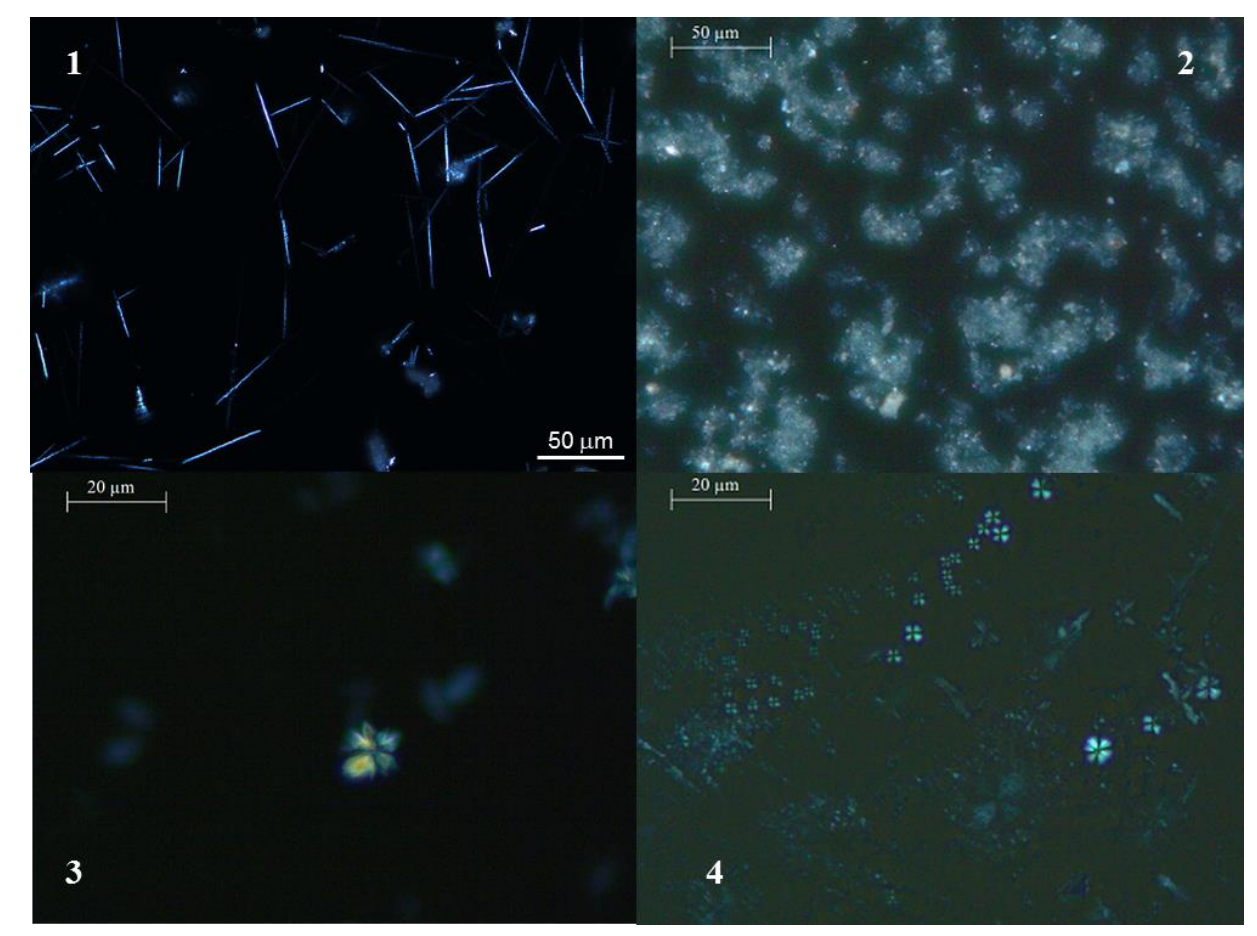

Figure 10. Optical microscopy images of 2-days old dried samples of $c a \cdot 1 \cdot 10^{-4} \mathrm{M}$ aqueous solutions of 1-4 under polarized light.

An unusual behavior was detected for the heterometallic complexes. The larger aggregates are aligned in different planes, as observed by changing the polarization angle (Figure 11 and S26). This long-range orientational order is analogous to that 
observed in lyotropic chromonic liquid crystals (LCLCs). ${ }^{41}$ These species have shown promising applications as polarizing films and security labels, templates for controlled assembly of nanostructures, including peptide amphiphiles, fabrication of microelectronic devices, electro-optic devices, etc. To the best of our knowledge, this nice example of an on/off heterometallic supramolecular polarized organization in water has no precedent in the literature.

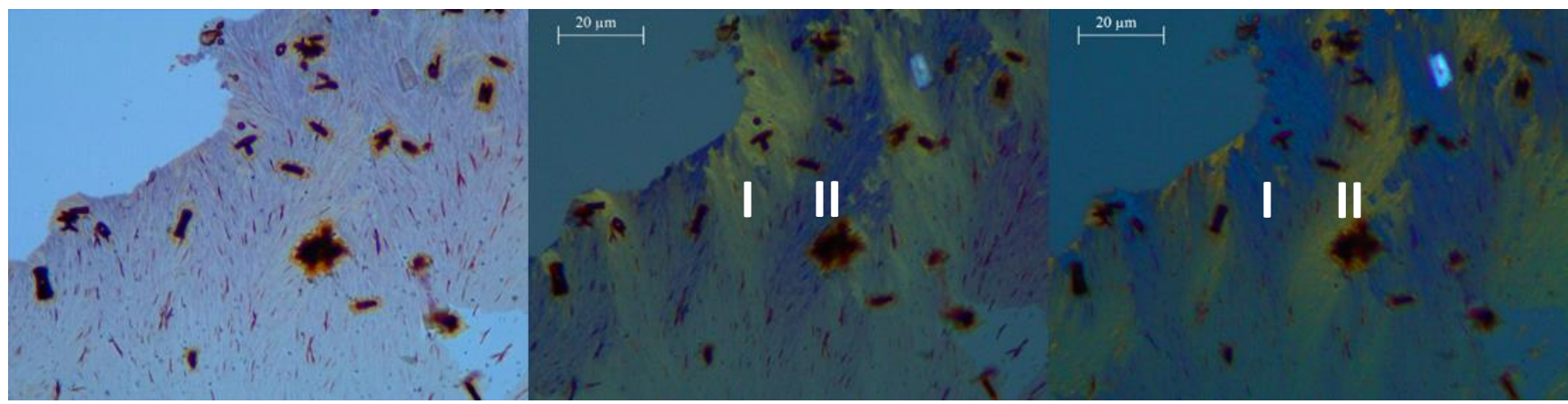

Figure 11. Optical microscopy images of $1 \cdot 10^{-4} \mathrm{M}$ fresh sample of $\mathbf{3}$ without polarization (left) and between cross-polarizers using an angle of $65^{\circ}$ (middle) and $85^{\circ}$ (right). Regions I and II change color with the polarization angle, from yellow to blue and vice versa.

Fluorescence microscopy supports these data andgreen emissive aggregates can be observed (Figure 12 left) in agreement with the previous emission spectra displayed in solid state (largest aggregation state, Figure 8). Additionally, the higher resulting entangled aggregates can be better observed under transmission electron microscopy. Very large dendritic structures in the range of micrometers size are the result of the intermolecular interactions in the heterometallic complexes (Figure 12 right). 


\section{Tuning shapes and emission with counterions}

As previously reported with other gold(I) supramolecular structures, ${ }^{11,42}$ counterions can play a direct role on the resulting emissive properties of complexes. With this goal in mind, compounds $\mathbf{1}$ and $\mathbf{2}$ were treated with different silver salts, as nitrate and triflate, following the same experimental procedure previously described for the hexafluorophosphate derivatives $\mathbf{3}$ and $\mathbf{4}$. The corresponding multinuclear NMR spectra show the correct formation of all the complexes. Two different trends were observed for the PTA and DAPTA derivatives. For the first group, the recorded downfield shift of the phosphane protons depends on the counterion being larger effect with respect to the gold(I) mononuclear complex 1, those complexes containing counterions, triflate and hexafluorophophate, able to establish F...H bonds with the complex (see Figures 13). This is a clear indication about the role of the counterion in the resulting package. It seems that the anion with higher solubility in water and without any fluorine atom (nitrate) can have a weaker interaction with the heterometallic complex, while triflate and hexafluorophosphate try to avoid water (hydrophobic effect) and are closely connected to the corresponding complex by the establishment of F $\cdots \mathrm{H}$ bonds. On the contrary, a significant interaction of the nitrate counterion is expected for DAPTA derivatives, due to the larger recorded downfield shift. This could be due to the presence of four possible positions in the nitrate to establish hydrogen bonds with the complex. 
Figure 13. ${ }^{1} \mathrm{H}-\mathrm{NMR}$ spectra of heterometallic complexes synthesized from $\mathbf{1}$ and $\mathrm{AgPF}_{6}$ (3), $\mathrm{AgNO}_{3}(\mathbf{5})$ and AgOTf (6) in acetone- $d_{6}$.

Moreover, their ${ }^{19} \mathrm{~F}-\mathrm{NMR}$ and ${ }^{31} \mathrm{P}$ - NMR spectra follow the same trend (Figures S27S31). In particular, the fluorine atoms of the organometallic part of the complexes follow the same trend detailed for protons, with the para fluorine atoms as the most affected in the formation of the complex.

The emission spectra recorded for the solids are in agreement with previous facts. In the case of the PTA derivatives, nitrate heterometallic complex displays the largest redshift. A plausible explanation based on all the recorded data is due to the smaller steric hindrance of the anion that favors the proximity between gold atoms (or gold/silver atoms), and thus, metallophilic contacts (Figure S32). In the case of the DAPTA complexes, the presence of acetyl units as additional points to establish hydrogen bonds with the anions, has a direct influence on the recorded emission spectra. In this way, the presence of triflate and hexafluorophosphate (with higher number of atoms potentially being involved on the establishment of weak interactions) results on a more significant red-shift of the emission, in comparison with nitrate (Figure 14). 

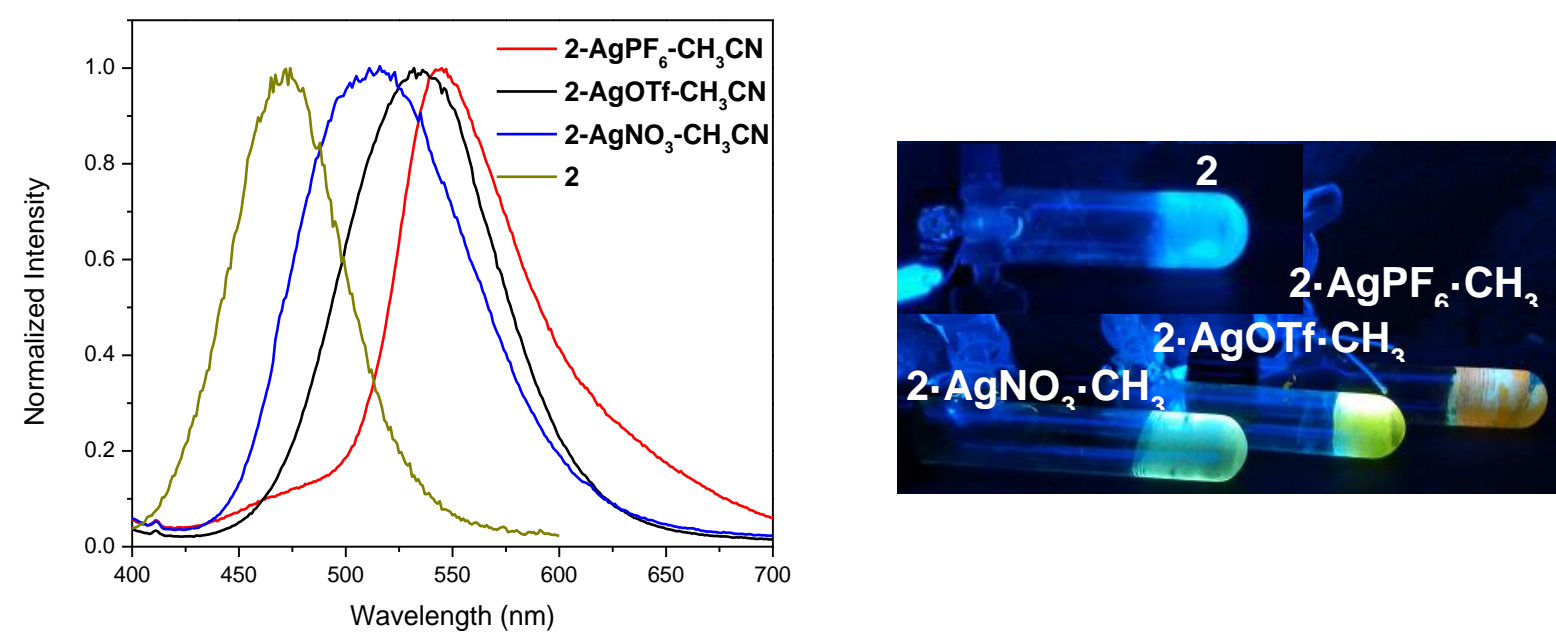

Figure 14. Normalized emission spectra of $\mathbf{2}$ and heterometallic complexes with nitrate, triflate and hexafluorophosphate silver salts (left); image of the solids observed under UV light (right).

\begin{abstract}
Absorption and emission spectra of the new complexes recorded at different concentrations present similar profile to those recorded for 3 and 4 (Figures S33-S40). The analysis of the morphology of the resulting aggregates in water has been performed looking at the samples under optical microscopy with polarized light (Figure S41). In the case of the triflate derivatives, the corresponding pattern is similar to that previously observed for the hexafluorphosphate one, with dendritic-like morphologies. Nitrate complexes induce a change on the morphology with spherical structures. In general, the size of the organized nitrate aggregates is smaller than for the other complexes. Thus, the effect of the particular counterion on the resulting aggregates's size and morphology,as well as on their intrinsic luminescent properties, has been evidenced.
\end{abstract}




\section{Conclusions}

The introduction of a water-soluble phosphane (PTA, DAPTA) as a second coordination ligand of an organometallic $\mathrm{Au}-\mathrm{C}_{6} \mathrm{~F}_{5}$ moiety gives rise to the formation of water-soluble perhalogenated complexes $\mathbf{1}$ and $\mathbf{2}$. The use of absorption, emission and microscopic techniques evidenced the formation of aggregates at high concentrations.

Additionally, the resulting aggregates' size, shapes, and luminescent properties can be modulated by the interaction with silver salts with expected $\mathrm{Au} \cdots \mathrm{Ag}$ metallophilic contacts, as evidenced by their X-ray crystal structures.

The resulting heterometallic complexes are also soluble in water and give rise to different aggregates morphologies depending on the counterion and the phosphane. That is, nitrate counterion gives rise to smaller and spherical aggregates, while the use of fluorinated counterions such as hexafluorophosphate or triflate induces the formation of larger and dendritric supramolecular structures.

Multinuclear NMR and luminescent studies indicate the degree of interaction between the different counterions and compounds $\mathbf{1}$ and $\mathbf{2}$, with larger downfield chemical shifts and more red-shifted emission bands for stronger interactions.

Finally, observation of the samples under optical microscopy with polarized light shows that the aggregates' organization depends on the polarization angle, as observed for LCLCs. 


\section{Experimental Section}

\section{General procedures}

All manipulations have been performed under prepurified $\mathrm{N}_{2}$ using standard Schlenk techniques. All solvents have been distilled from appropriated drying agents. Commercial reagents 1,3,5-triaza-7-phosphatricyclo[3.3.1.13.7]decane (PTA, Aldrich 97\%), 3,7-diacetyl-1,3,7-triaza-5- phosphabicyclo[3.3.1]nonane (DAPTA, Aldrich 97\%), $\mathrm{AgCF}_{3} \mathrm{SO}_{3}$ (AgOTf, Aldrich 98\%), silver nitrate (Panreac, 97\%) and silver hexafluorophosphate (Aldrich, 98\%) have been used as received. Literature methods have been used to prepare $\left[\mathrm{Au}(\mathrm{tht})\left(\mathrm{C}_{6} \mathrm{~F}_{5}\right)\right]^{43}$ and $\left[\mathrm{Au}\left(\mathrm{C}_{6} \mathrm{~F}_{5}\right)(\mathrm{PTA})\right]^{22}$

\section{Physical measurements}

Infrared spectra have been recorded on a FT-IR 520 Nicolet Spectrophotometer. ${ }^{1} \mathrm{H}$ $\operatorname{NMR}(\delta(\mathrm{TMS})=0.0 \mathrm{ppm}),{ }^{31} \mathrm{P}\left\{{ }^{1} \mathrm{H}\right\}-\mathrm{NMR}\left(\delta\left(85 \% \mathrm{H}_{3} \mathrm{PO}_{4}\right)=0.0 \mathrm{ppm}\right)$ and ${ }^{19} \mathrm{~F}\left\{{ }^{1} \mathrm{H}\right\}$ $\left(\delta\left(\mathrm{CFCl}_{3}\right)=0.0 \mathrm{ppm}\right)$ spectra have been obtained on a Varian Mercury 400 and Bruker 400 (Universitat de Barcelona). Elemental analyses of $\mathrm{C}, \mathrm{H}$ and $\mathrm{N}$ have been carried out at the Centres Científics i Tecnològics de la Universitat de Barcelona (CCiTUB). ElectroSpray-Mass spectra (+) has been recorded on a Fisons VG Quatro spectrometer (Universitat de Barcelona). Absorption spectra have been recorded on a Varian Cary 100 Bio UV- spectrophotometer and emission spectra on a Horiba-Jobin-Ybon SPEX Nanolog spectrofluorimeter (Universitat de Barcelona). Fluorescence microscopy have been recorded on a Leica DMIRB fluorescence microscope (Universitat de Barcelona). Scanning electron microscopy has been carried out a $5 \mathrm{kV}$ using a Neon40 Crossbeam Station (Zeiss) equipped with a field emission gun (Universitat Politècnica de Catalunya). Optical microscopy images have been acquired on a Leica ICC50 W (Universitat de Barcelona). TEM images were recorded with a Tecnai G2 Spirit.

\section{Crystallography}

Crystals were mounted in inert oil on glass fibers and transferred to the cold gas stream of a Noinus Kappa CCD (1) or a Bruker APEX-II CCD diffractometer $\left(\mathbf{2} \cdot 0.5 \mathrm{H}_{2} \mathrm{O}\right.$ and 4. $\mathrm{NCMe} \cdot \mathrm{Me}_{2} \mathrm{CO} \cdot 0.5 \mathrm{H}_{2} \mathrm{O}$ ) equipped with an Oxford Instruments low-temperature attachment. Data were collected using monochromated Mo K $\alpha$ radiation $(\lambda=0.71073$ 
$\AA$ ). Scan type $\omega$ and $\phi$. Absorption effects were treated by semiempirical corrections based on multiple scans. The structures were solved by direct methods and refined on $F^{2}$ using the program SHELXL-97.[3] All non-hydrogen atoms were refined anisotroplically, and hydrogen atoms were included using riding model. Selected bond lengths and angles are collected in Tables 1, 2, S1-S4, and crystal structures of complexes 1, 2.0.5 $\mathrm{H}_{2} \mathrm{O}$ and $\mathbf{4} \cdot \mathrm{NCMe} \cdot \mathrm{Me}_{2} \mathrm{CO} \cdot 0.5 \mathrm{H}_{2} \mathrm{O}$ are shown in Figures 4 and 6. CCDC 1563994-1563996 contain the supplementary crystallographic data for this paper. These data can be obtained free of charge via www.ccdc.cam.ac.uk/conts/retrieving.html (or from the Cambridge Crystallographic Data Centre, 12 Union Road, Cambridge CB2 1EZ, UK; fax: (+44) 1223-336-033; or email: deposit@ccdc.cam.ac.uk).

\section{Synthesis and Characterization}

\section{Synthesis of $\left[\mathrm{Au}\left(\mathrm{C}_{6} \mathbf{F}_{5}\right)(\right.$ PTA $\left.)\right](1)$}

The compound was prepared following an analogous procedure to that reported in literature $($ yield $=63 \%){ }^{22}$

${ }^{31} \mathrm{P}\left\{{ }^{1} \mathrm{H}\right\}-\mathrm{NMR}$ (acetone- $\left.d_{6}, \mathrm{ppm}\right):-47.2 .{ }^{1} \mathrm{H}-\mathrm{NMR}$ (acetone- $\left.d_{6}, \mathrm{ppm}\right): 4.48$ (s, 6H, N$\mathrm{CH}_{2}-\mathrm{P}$ ), 4.52-4.72 (AB q, J = 13.0 Hz, 6H, N-CH $\mathrm{CH}_{2}-\mathrm{N}$ ). ${ }^{19} \mathrm{~F}-\mathrm{NMR}$ (acetone- $d_{6}$, ppm): 164.1 (m, m-F), -160.8 (t, J = $19.7 \mathrm{~Hz}, \mathrm{p}-\mathrm{F}),-116.7$ (m, o-F). IR (KBr, cm $\left.{ }^{-1}\right): v(\mathrm{Au}-$ $\left.\mathrm{C}_{6} \mathrm{~F}_{5}\right): 1504,947,743 ; v\left(\mathrm{CH}_{2}-\mathrm{P}\right): 1459 ; v(\mathrm{C}-\mathrm{N}):$ 1237. ESI-MS (+) $m / z: 522.04$ $\left([\mathrm{M}+\mathrm{H}]^{+}\right.$, calc: 522.04). Anal. Calc.: C $27.65 \%$, N $8.06 \%$, H 2.32; Found: C $27.74 \%$, N $7.98 \%$, H $2.40 \%$.

\section{Synthesis of $\left[\mathrm{Au}\left(\mathrm{C}_{6} \mathrm{~F}_{5}\right)(\mathrm{DAPTA})\right](2)$}

In a typical procedure, solid DAPTA (144 $\mathrm{mg}, 0.243 \mathrm{mmol})$ was added to a solution of [ $\left.\mathrm{Au}\left(\mathrm{C}_{6} \mathrm{~F}_{5}\right)(\mathrm{tht})\right](110 \mathrm{mg}, 0.243 \mathrm{mmol})$ in $\mathrm{CH}_{2} \mathrm{Cl}_{2}(10 \mathrm{~mL})$ and stirred for $2 \mathrm{~h}$. The solution was concentrated to $5 \mathrm{~mL}$ and then hexane was added to precipitate a white solid in $65 \%$ yield.

${ }^{31} \mathrm{P}\left\{{ }^{1} \mathrm{H}\right\}-\mathrm{NMR}$ (acetone- $\left.d_{6}, \mathrm{ppm}\right):-18.3 .{ }^{1} \mathrm{H}-\mathrm{NMR}$ (acetone- $\left.d_{6}, \mathrm{ppm}\right): 2.09$ (m, 6H, COMe), 3.82 (m, 1H, N-CH $-\mathrm{P}$ ), 4.18 (s, 2H, N-CH $-\mathrm{P}$ ), 4.25 (d, J = 13.9 Hz, 1H, N$\left.\mathrm{CH}_{2}-\mathrm{N}\right), 4.45$ (m, 1H, N-CH $\left.2-\mathrm{P}\right), 4.85$ (m, 1H, N-CH $\left.2-\mathrm{P}\right), 4.99-5.12$ (m, 2H, N-CH $2-\mathrm{N}$ ), 


\section{Synthesis of $\left[\mathrm{AuAg}\left(\mathrm{C}_{6} \mathrm{~F}_{5}\right)(\mathrm{PTA})\right] \mathrm{PF}_{6}(3)$}

Solid $\mathrm{AgPF}_{6}(72.8 \mathrm{mg}, 0.288 \mathrm{mmol})$ was added to a solution of 1 (50 mg, $\left.0.096 \mathrm{mmol}\right)$ in $\mathrm{CH}_{3} \mathrm{CN}(15 \mathrm{~mL})$. The solution was stirred during $1 \mathrm{~h}$ and then evaporated to dryness under vacuum to yield an orange solid.

${ }^{31} \mathrm{P}\left\{{ }^{1} \mathrm{H}\right\}-\mathrm{NMR}$ (acetone- $\left.d_{6}, \mathrm{ppm}\right):-42.5$ (PTA), -144.3 (m, $\left.\mathrm{PF}_{6}{ }^{-}\right) .{ }^{1} \mathrm{H}-\mathrm{NMR}$ (acetone- $d_{6}$, ppm): ${ }^{1} \mathrm{H}-\mathrm{NMR}$ (acetone- $\left.d_{6}, \mathrm{ppm}\right): 2.07$ (s, $\mathrm{CH}_{3} \mathrm{CN}$, overlapped with acetone- $d_{6}$ signal), $4.60\left(\mathrm{~s}, 6 \mathrm{H}, \mathrm{N}-\mathrm{CH}_{2}-\mathrm{P}\right), 4.74-4.90\left(\mathrm{AB} \mathrm{q}, \mathrm{J}=13.1 \mathrm{~Hz}, 6 \mathrm{H}, \mathrm{N}-\mathrm{CH}_{2}-\mathrm{N}\right) .{ }^{19} \mathrm{~F}-\mathrm{NMR}$ (acetone- $\left.d_{6}, \mathrm{ppm}\right)$ : -164.0 (m, m-F), -160.5 (t, J = 20.4 Hz, p-F), -116.7 (m, o-F), -72.4 $\left(\mathrm{d}, \mathrm{J}=530.6 \mathrm{~Hz}, \mathrm{PF}_{6}{ }^{-}\right)$. IR $\left(\mathrm{KBr}, \mathrm{cm}^{-1}\right): v\left(\mathrm{Au}-\mathrm{C}_{6} \mathrm{~F}_{5}\right): 1500,978,700 ; v\left(\mathrm{CH}_{2}-\mathrm{P}\right): 1455$; $v(\mathrm{C}-\mathrm{N}): 1241 ; v\left(\mathrm{PF}_{6}{ }^{-}\right): 840,551$. ESI-MS $(+) \mathrm{m} / z: 1276.88\left(\left[\left[\mathrm{Au}_{2} \mathrm{Ag}_{2}\left(\mathrm{C}_{6} \mathrm{~F}_{5}\right)_{2}(\mathrm{PTA})_{2}\right] \mathrm{F}\right]^{+}\right.$, calc.: 1276.88), $1402.85\left(\left[\left[\mathrm{Au}_{2} \mathrm{Ag}_{2}\left(\mathrm{C}_{6} \mathrm{~F}_{5}\right)_{2}(\mathrm{PTA})_{2}\right] \mathrm{PF}_{6}\right]^{+}\right.$, calc.: 1402.84). Anal Cal. for $\mathrm{C}_{12} \mathrm{H}_{12} \mathrm{~N}_{3} \mathrm{~F}_{11} \mathrm{P}_{2} \mathrm{AgAu} \cdot 0.5 \mathrm{CH}_{3} \mathrm{CN} \cdot \mathrm{H}_{2} \mathrm{O}$ : C $19.22 \%$, N 6.03\% H 1.92\%; Found: $\mathrm{C}$ $19.16 \%$, N $5.95 \%, \mathrm{H} 2.04 \%$.

\section{Synthesis of $\left[\mathrm{AuAg}\left(\mathrm{C}_{6} \mathrm{~F}_{5}\right)(\mathrm{DAPTA}) \mathrm{PF}_{6}\right.$ (4)}

Solid $\mathrm{AgPF}_{6}(21.3 \mathrm{mg}, 0.084 \mathrm{mmol})$ was added to a solution of $2(50 \mathrm{mg}, 0.084 \mathrm{mmol})$ in $\mathrm{CH}_{3} \mathrm{CN}(15 \mathrm{~mL})$. The solution was stirred during $1 \mathrm{~h}$ and then evaporated to dryness under vacuum to yield an orange solid.

${ }^{31} \mathrm{P}\left\{{ }^{1} \mathrm{H}\right\}-\mathrm{NMR}$ (acetone- $\left.d_{6}, \mathrm{ppm}\right):-17.9$ (m, DAPTA), -144.3 (m, $\left.\mathrm{PF}_{6}{ }^{-}\right) .{ }^{1} \mathrm{H}-\mathrm{NMR}$ (acetone- $\left.d_{6}, \mathrm{ppm}\right): 2.05\left(\mathrm{CH}_{3} \mathrm{CN}\right.$, overlapped with acetone- $d_{6}$ signal), $2.09(\mathrm{~m}, 6 \mathrm{H}$, COMe), 3.82 (m, 1H, N-CH $2-\mathrm{P}), 4.19$ (s, 2H, N-CH $-\mathrm{P}), 4.25$ (d, J = $14.0 \mathrm{~Hz}, 1 \mathrm{H}, \mathrm{N}-$ $\mathrm{CH}_{2}-\mathrm{N}$ ), 4.45 (m, 1H, N-CH $-\mathrm{P}$ ), 4.86 (m, 1H, N-CH $-\mathrm{P}$ ), 4.99-5.13 (m, 2H, N-CH $-\mathrm{N}$ ), $5.65\left(\mathrm{~m}, 1 \mathrm{H}, \mathrm{N}-\mathrm{CH}_{2}-\mathrm{P}\right), 5.75\left(\mathrm{~d}, \mathrm{~J}=14.0 \mathrm{~Hz}, 1 \mathrm{H}, \mathrm{N}-\mathrm{CH}_{2}-\mathrm{N}\right) .{ }^{19} \mathrm{~F}-\mathrm{NMR}$ (acetone- $d_{6}$, ppm): -164.0 (m, m-F), -160.4 (t, J = 20.4 Hz, p-F), -116.6 (m, o-F), -73.1 (d, J = 530.6 $\left.\mathrm{Hz}, \mathrm{PF}_{6}{ }^{-}\right) . \mathrm{IR}\left(\mathrm{KBr}, \mathrm{cm}^{-1}\right): v(\mathrm{C}=\mathrm{O}): 1637 ; v\left(\mathrm{Au}-\mathrm{C}_{6} \mathrm{~F}_{5}\right): 1500,952,700 ; v\left(\mathrm{CH}_{2}-\mathrm{P}\right): 1454$; 
$v(\mathrm{C}-\mathrm{N}) \quad$ at $\quad 1232 ; \quad v\left(\mathrm{PF}_{6}^{-}\right): \quad 840, \quad 560 . \quad$ ESI-MS $\quad(+) \quad m / z: 1546.89$ $\left(\left[\left[\mathrm{Au}_{2} \mathrm{Ag}_{2}\left(\mathrm{C}_{6} \mathrm{~F}_{5}\right)_{2}(\mathrm{DAPTA})_{2}\right] \mathrm{PF}_{6}\right]^{+}\right.$, calc.: 1546.89). Anal. Calc. for $\mathrm{C}_{15} \mathrm{H}_{16} \mathrm{AgAuF}_{11} \mathrm{~N}_{3} \mathrm{O}_{2} \mathrm{P}_{2} \cdot 0.5 \mathrm{CH}_{3} \mathrm{CN}$ : C $27.65 \%, \mathrm{~N} 8.06 \%, \mathrm{H} 2.32$; Found: C 27.20\%, N $8.10 \%, \mathrm{H} 2.43 \%$.

\section{Synthesis of $\left[\mathrm{AuAg}\left(\mathrm{C}_{6} \mathrm{~F}_{5}\right)(\mathrm{PTA})\right] \mathrm{NO}_{3}(5)$}

Similar procedure was used in the synthesis of $\mathbf{5}$ with respect to $\mathbf{3}$ but using $\mathrm{AgNO}_{3}$ instead of $\mathrm{AgPF}_{6}$ and in 1:1 ratio (gold precursor: silver salt). Yield: $47 \%$.

${ }^{31} \mathrm{P}\left\{{ }^{1} \mathrm{H}\right\}$-NMR (acetone- $\left.d_{6}, \mathrm{ppm}\right):-45.2 .{ }^{1} \mathrm{H}-\mathrm{NMR}$ (acetone- $d_{6}, \mathrm{ppm}$ ): 4.55 (s, 6H, N$\left.\mathrm{CH}_{2}-\mathrm{P}\right), 4.64-4.81\left(\mathrm{AB} q, \mathrm{~J}=12.8 \mathrm{~Hz}, 6 \mathrm{H}, \mathrm{N}-\mathrm{CH}_{2}-\mathrm{N}\right) .{ }^{19} \mathrm{~F}-\mathrm{NMR}$ (acetone- $d_{6}, \mathrm{ppm}$ ): 164.9 (m, m-F), -162.8 (t, J = $21.2 \mathrm{~Hz}, \mathrm{p}-\mathrm{F}),-115.3(\mathrm{~m}, \mathrm{o}-\mathrm{F}) . \mathrm{IR}\left(\mathrm{KBr}, \mathrm{cm}^{-1}\right): v(\mathrm{Au}-$ $\left.\mathrm{C}_{6} \mathrm{~F}_{5}\right): 1510,947,791 ; v\left(\mathrm{CH}_{2}-\mathrm{P}\right): 1459 ; v\left(\mathrm{NO}_{3}{ }^{-}\right): 1383 ; v(\mathrm{C}-\mathrm{N}): 1276$. ESI-MS (+) $\mathrm{m} / z$ : $[\mathrm{M}]^{+}$calculated for $\mathrm{C}_{12} \mathrm{H}_{12} \mathrm{~N}_{3} \mathrm{~F}_{5} \mathrm{PAgAu}, 627.940$; found, 627.9402; 1276.88 $\left(\left[\left[\mathrm{Au}_{2} \mathrm{Ag}_{2}\left(\mathrm{C}_{6} \mathrm{~F}_{5}\right)_{2}(\mathrm{PTA})_{2}\right] \mathrm{F}\right]^{+}\right.$, calc.: 1276.88$)$ Anal Cal. for $\mathrm{C}_{12} \mathrm{H}_{12} \mathrm{~N}_{4} \mathrm{~F}_{5} \mathrm{O}_{3} \mathrm{PAgAu} \cdot 0.5 \mathrm{CH}_{3} \mathrm{CN}$ : C $21.94 \%, \mathrm{~N} 8.86 \% \mathrm{H} 1.91 \%$; Found: C $22.10 \%, \mathrm{~N}$ $8.93 \%, \mathrm{H} 1.93 \%$.

\section{Synthesis of $\left[\operatorname{AuAg}\left(\mathrm{C}_{6} \mathbf{F}_{5}\right)(\mathrm{PTA})\right] \mathrm{OTf}(6)$}

Similar procedure was used in the synthesis of $\mathbf{6}$ with respect to $\mathbf{5}$ but using AgOTf instead of $\mathrm{AgPF}_{6}$. Yield: $77 \%$.

${ }^{31} \mathrm{P}\left\{{ }^{1} \mathrm{H}\right\}-\mathrm{NMR}$ (acetone- $\left.d_{6}, \mathrm{ppm}\right):-35.7 .{ }^{1} \mathrm{H}-\mathrm{NMR}$ (acetone- $\left.d_{6}, \mathrm{ppm}\right): 2.07\left(\mathrm{CH}_{3} \mathrm{CN}\right.$, overlapped with acetone- $d_{6}$ signal), $4.72\left(\mathrm{~s}, 6 \mathrm{H}, \mathrm{N}-\mathrm{CH}_{2}-\mathrm{P}\right), 4.99-5.09$ ( $\mathrm{AB} q, \mathrm{~J}=13.2$ $\left.\mathrm{Hz}, 6 \mathrm{H}, \mathrm{N}-\mathrm{CH}_{2}-\mathrm{N}\right) .{ }^{19} \mathrm{~F}$ (acetone- $\left.d_{6}, \mathrm{ppm}\right):-163.8(\mathrm{~m}, \mathrm{~m}-\mathrm{F}),-157.7$ (t, J = $20.8 \mathrm{~Hz}, \mathrm{p}-$ F), -116.2 (m, o-F), -78.5 (s, $\left.\mathrm{CF}_{3} \mathrm{SO}_{3}{ }^{-}\right) . \mathrm{IR}\left(\mathrm{KBr}, \mathrm{cm}^{-1}\right): v\left(\mathrm{Au}-\mathrm{C}_{6} \mathrm{~F}_{5}\right): 1508,947,700$; $v\left(\mathrm{CH}_{2}-\mathrm{P}\right): 1450 ; v\left(\mathrm{CF}_{3} \mathrm{SO}_{3}{ }^{-}\right): 1259$. ESI-MS $(+) m / z: 627.940\left(\left[\mathrm{AuAg}\left(\mathrm{C}_{6} \mathrm{~F}_{5}\right)(\mathrm{PTA})\right]^{+}\right.$, calc.: 627.940) $668.966\left(\left[\left[\mathrm{AuAg}\left(\mathrm{C}_{6} \mathrm{~F}_{5}\right)(\mathrm{PTA})\right] \mathrm{CH}_{3} \mathrm{CN}\right]^{+}\right.$, calc.: 668.966), 1404.832 $\left(\left[\left[\mathrm{Au}_{2} \mathrm{Ag}_{2}\left(\mathrm{C}_{6} \mathrm{~F}_{5}\right)_{2}(\mathrm{PTA})_{2}\right] \mathrm{OTf}\right]^{+}\right.$, calc.: 1406.833). Anal Cal. for $\mathrm{C}_{13} \mathrm{H}_{12} \mathrm{~N}_{4} \mathrm{~F}_{8} \mathrm{O}_{3} \mathrm{PSAgAu} \cdot 0.5 \mathrm{CH}_{3} \mathrm{CN} \cdot \mathrm{H}_{2} \mathrm{O}$ : C 27.90\%, N 8.76\% H 2.79\%; Found: $\mathrm{C}$ $27.84 \%, \mathrm{~N} 8.81 \%, \mathrm{H} 2.80 \%$.

\section{Synthesis of $\left[\operatorname{AuAg}\left(\mathrm{C}_{6} \mathrm{~F}_{5}\right)(\mathrm{DAPTA})\right] \mathrm{NO}_{3}(7)$}

Similar procedure was used in the synthesis of 7 with respect to 4 but using $\mathrm{AgNO}_{3}$ instead of $\mathrm{AgPF}_{6}$. Yield: $30 \%$. 
${ }^{31} \mathrm{P}\left\{{ }^{1} \mathrm{H}\right\}-\mathrm{NMR}$ (acetone- $\left.d_{6}, \mathrm{ppm}\right):-17.7 .{ }^{1} \mathrm{H}-\mathrm{NMR}$ (acetone- $\left.d_{6}, \mathrm{ppm}\right): 2.08$ (m, 6H, COMe), 3.81 (t, J = $\left.16 \mathrm{~Hz}, 1 \mathrm{H}, \mathrm{N}-\mathrm{CH}_{2}-\mathrm{P}\right), 4.28-4.16\left(\mathrm{~m}, 3 \mathrm{H}, \mathrm{N}-\mathrm{CH}_{2}-\mathrm{P}+\mathrm{N}_{-} \mathrm{CH}_{2}-\mathrm{N}\right)$, 4.44 (m, 1H, N-CH2-P), 4.86 (d, J= 15.6, 1H, N-CH2-N), 4.97-5.12 (m, 2H, N-CH2-P + $\left.\mathrm{N}-\mathrm{CH}_{2}-\mathrm{N}\right), 5.58-5.77\left(\mathrm{~m}, 2 \mathrm{H}, \mathrm{N}-\mathrm{CH}_{2}-\mathrm{P}+\mathrm{N}-\mathrm{CH}_{2}-\mathrm{N}\right) .{ }^{19} \mathrm{~F}-\mathrm{NMR}$ (acetone- $d_{6}, \mathrm{ppm}$ ): 163.9 (m, m-F), -160.1 (t, J = 20.4 Hz, p-F), -116.3 (m, o-F). IR $\left(\mathrm{KBr}, \mathrm{cm}^{-1}\right): v(\mathrm{C}=\mathrm{O})$ : $1645 ; v\left(\mathrm{Au}-\mathrm{C}_{6} \mathrm{~F}_{5}\right): 1503,954,800 ; v\left(\mathrm{CH}_{2}-\mathrm{P}\right): 1450 ; v\left(\mathrm{NO}_{3}{ }^{-}\right): 1384 ; v(\mathrm{C}-\mathrm{N}): 1261$. ESIMS $\quad(+) \quad m / z: \quad 699.961 \quad\left(\left[\operatorname{AuAg}\left(\mathrm{C}_{6} \mathrm{~F}_{5}\right)(\mathrm{DAPTA})\right]^{+}, \quad\right.$ calc.: 699.961$), 1461.911$ $\left(\left[\left[\mathrm{Au}_{2} \mathrm{Ag}_{2}\left(\mathrm{C}_{6} \mathrm{~F}_{5}\right)_{2}(\mathrm{DAPTA})_{2}\right] \mathrm{NO}_{3}\right]^{+}\right.$, calc.: 1493.911). Anal. Calc. for $\mathrm{C}_{15} \mathrm{H}_{16} \mathrm{AgAuF}_{5} \mathrm{~N}_{4} \mathrm{O}_{5} \mathrm{P} \cdot 0.5 \mathrm{CH}_{3} \mathrm{CN}$ : C $24.52 \%, \mathrm{~N} 8.04 \%, \mathrm{H} 2.25$; Found: C 24.61\%, N $8.06 \%, \mathrm{H} 2.27 \%$.

\section{Synthesis of $\left[\operatorname{AuAg}\left(\mathrm{C}_{6} \mathrm{~F}_{5}\right)(\mathrm{DAPTA})\right] \mathrm{OTf}(8)$}

Similar procedure was used in the synthesis of 8 with respect to 4 but using AgOTf instead of $\mathrm{AgPF}_{6}$. Yield: $20 \%$.

${ }^{31} \mathrm{P}\left\{{ }^{1} \mathrm{H}\right\}$-NMR (acetone- $\left.d_{6}, \mathrm{ppm}\right):-17.8 .{ }^{1} \mathrm{H}-\mathrm{NMR}$ (acetone- $\left.d_{6}, \mathrm{ppm}\right): 2.05\left(\mathrm{CH}_{3} \mathrm{CN}\right.$, overlapped with acetone- $d_{6}$ signal), 2.08 (s, 3H, COMe), 2.09 (s, 3H, COMe), 3.80 (dt, J $\left.=15.6 \mathrm{~Hz}, 3.2 \mathrm{~Hz}, 1 \mathrm{H}, \mathrm{N}-\mathrm{CH}_{2}-\mathrm{P}\right), 4.17$ (s, 2H, N-CH $\left.-\mathrm{P}\right), 4.24$ (d, J = $14 \mathrm{~Hz}, 1 \mathrm{H}, \mathrm{N}-$ $\mathrm{CH}_{2}-\mathrm{N}$ ), 4.44 (dt, J = $\left.15.2 \mathrm{~Hz}, 4 \mathrm{~Hz}, 1 \mathrm{H}, \mathrm{N}-\mathrm{CH}_{2}-\mathrm{P}\right), 4.84$ (d, J = $14 \mathrm{~Hz}, 1 \mathrm{H}, \mathrm{N}-\mathrm{CH}_{2}-\mathrm{N}$ ), 4.99 (d, J = 10.4 Hz, 1H, N-CH $-\mathrm{P}), 5.07$ (d, J = $\left.14 \mathrm{~Hz}, 1 \mathrm{H}, \mathrm{N}-\mathrm{CH}_{2}-\mathrm{N}\right), 5.62$ (dd, J = 16 $\left.\mathrm{Hz}, 8 \mathrm{~Hz}, 1 \mathrm{H}, \mathrm{N}-\mathrm{CH}_{2}-\mathrm{P}\right), 5.73\left(\mathrm{~d}, \mathrm{~J}=14 \mathrm{~Hz}, 1 \mathrm{H}, \mathrm{N}-\mathrm{CH}_{2}-\mathrm{N}\right.$ ). ${ }^{19} \mathrm{~F}-\mathrm{NMR}$ (acetone- $d_{6}$, ppm): -163.9 (m, m-F), -160.2 (t, J = $20.8 \mathrm{~Hz}, \mathrm{p}-\mathrm{F}),-116.5$ (m, o-F), -78.6 (s, $\left.\mathrm{CF}_{3} \mathrm{SO}_{3}{ }^{-}\right)$. IR $\left(\mathrm{KBr}, \mathrm{cm}^{-1}\right): v(\mathrm{C}=\mathrm{O})$ at $1646 ; v\left(\mathrm{Au}-\mathrm{C}_{6} \mathrm{~F}_{5}\right)$ at $1504,952,796 ; v\left(\mathrm{CH}_{2}-\mathrm{P}\right)$ at 1450 ; $v\left(\mathrm{CF}_{3} \mathrm{SO}_{3}{ }^{-}\right)$at 1259. ESI-MS (+) $m / z: 699.961 \quad\left(\left[\mathrm{AuAg}\left(\mathrm{C}_{6} \mathrm{~F}_{5}\right)(\mathrm{DAPTA})\right]^{+}\right.$, calc.: 699.961), $1548.875\left(\left[\left[\mathrm{Au}_{2} \mathrm{Ag}_{2}\left(\mathrm{C}_{6} \mathrm{~F}_{5}\right)_{2}(\mathrm{DAPTA})_{2}\right] \mathrm{OTf}\right]^{+}\right.$, calc.: 1550.875. Anal. Calc. for $\mathrm{C}_{16} \mathrm{H}_{16} \mathrm{AgAuF} \mathrm{N}_{4} \mathrm{O}_{5} \mathrm{SP} \cdot 0.5 \mathrm{CH}_{3} \mathrm{CN} \cdot \mathrm{H}_{2} \mathrm{O}: \mathrm{C} 22.98 \%$, N $5.52 \%, \mathrm{H} 2.21$; Found: $\mathrm{C}$ $23.12 \%, \mathrm{~N} 5.47 \%, \mathrm{H} 2.23 \%$.

\section{Acknowledgements}

Authors are grateful to the Ministerio de Ciencia e Innovación of Spain (AEI/FEDER, UE Projects CTQ2016-76120-P and CTQ2016-75816-C2-2-P). This research was supported by a Marie Curie Intra European Fellowship within the 7th European Community Framework Programme (R. G.). R. Donamaría thanks C.A.R. for a grant. 


\section{Supplementary Material}

${ }^{1} \mathrm{H}-\mathrm{NMR}$ spectrum of 1 in acetone- $d_{6 K}$ (Figure S1); ${ }^{31} \mathrm{P}-\mathrm{NMR}$ spectrum of $\mathbf{1}$ in acetone$d_{6}$ (Figure S2); ${ }^{19} \mathrm{~F}-\mathrm{NMR}$ spectrum of $\mathbf{1}$ in acetone- $d_{6}$ (Figure S3); ${ }^{1} \mathrm{H}-\mathrm{NMR}$ spectrum of 2 in acetone- $d_{6}$ (Figure S4); ${ }^{31} \mathrm{P}-\mathrm{NMR}$ spectrum of 2 in acetone- $d_{6}$ (Figure S5); ${ }^{19} \mathrm{~F}$ NMR spectrum of $\mathbf{2}$ in acetone- $d_{6}$ (Figure S6); ${ }^{19} \mathrm{~F}-\mathrm{NMR}$ spectra of $\mathbf{1}$ in the presence of $0,1,2$ and 3 equivalents of $\mathrm{AgPF}_{6}$, together with the spectrum of $\mathrm{AgPF}_{6}$ in acetone- $d_{6}$ (Figure S7); ${ }^{31} \mathrm{P}-\mathrm{NMR}$ spectra of $\mathbf{1}$ in the presence of $0,1,2$ and 3 equivalents of $\mathrm{AgPF}_{6}$ in acetone- $d_{6}$ (Figure S8); ${ }^{1} \mathrm{H}-\mathrm{NMR}$ spectra of 2 with increasing amounts of $\mathrm{AgPF}_{6}$ salt (0,1, 2 and 3 equivalents). Phosphane region (top) and acetonitrile region (bottom) in acetone- $d_{6}$ (Figure S9); ${ }^{19}$ F-NMR spectra of 2 in the presence of $0,1,2$ and 3 equivalents of $\mathrm{AgPF}_{6}$, together with the spectrum of $\mathrm{AgPF}_{6}$ in acetone- $d_{6}$ (Figure S10);

${ }^{31} \mathrm{P}-\mathrm{NMR}$ spectra of 2 in the presence of $0,1,2$ and 3 equivalents of $\mathrm{AgPF}_{6}$ in acetone$d_{6}$ (Figure S11); ESI-MS(+) spectrum of $2 \cdot \mathrm{AgPF}_{6}$ (Figure S12); ORTEP representation of X-ray structure of $\mathbf{1}$ (left) and $\mathbf{2}$ (right) (Figure S13); Representation of the packing of 1 showing the dimeric alignment (Figure S14); Zig-zag packing of $\mathbf{1}$. Thermal ellipsoids are drawn at the $50 \%$ probability (Figure S15); 1D polymeric network of 4. $\mathrm{NCMe} \cdot \mathrm{Me}_{2} \mathrm{CO} \cdot 0.5 \mathrm{H}_{2} \mathrm{O}$ formed via hydrogen bonds. Yellow: gold; blue: silver; orange: phosphorus; grey: carbon; light blue: nitrogen; red: oxygen and green: fluorine (Figure S17); Excitation and emission spectra of $\mathbf{3}$ and $\mathbf{4}$ at $1 \cdot 10^{-4} \mathrm{M}$ aqueous solution. (Figure S18); Normalized excitation spectra of complexes 1, 3 (left) and 2, 4 (right) in solid state (Figure S19); Normalized emission spectra of $\mathbf{1}, \lambda_{\mathrm{exc}}=375 \mathrm{~nm}$, and $\mathbf{1}$ in the presence of 1, 2 and 3 equivalents of $\mathrm{AgPF}_{6}, \lambda_{\mathrm{exc}}=420 \mathrm{~nm}$, (left); Normalized emission spectra of $2, \lambda_{\mathrm{exc}}=375 \mathrm{~nm}$, and 2 , in the presence of 1,2 and 3 equivalents of $\mathrm{AgPF}_{6}$, $\lambda_{\text {exc }}=420 \mathrm{~nm}$, (right) (Figure S20); Absorption spectra of 2 at different concentrations in water. Inset: Representation of absorption at $255 \mathrm{~nm}$ versus concentration (Figure S21); Absorption spectra of 3 at different concentrations in water. Inset: Representation of absorption at $255 \mathrm{~nm}$ versus concentration (Figure S22); Absorption spectra of 4 at different concentrations in water. Inset: Representation of absorption at $255 \mathrm{~nm}$ versus concentration (Figure S23); Emission spectra of $\mathbf{3}$ at different concentrations in water. Inset: Representation of emission at $455 \mathrm{~nm}$ versus concentration $\left(\lambda_{\mathrm{exc}}=380 \mathrm{~nm}\right)$ (Figure S24); Emission spectra of $\mathbf{4}$ at different concentrations in water. Inset: Representation of emission at $662 \mathrm{~nm}$ versus concentration. $\lambda_{\mathrm{exc}}=470 \mathrm{~nm}$ (Figure S25); Optical microscopy images between cross-polarizers of freshly prepared samples of $\mathbf{4}$ 
(A); 2 days (B) and 8 days in solution (C), at different polarization angles: $0^{\circ}(1), 70^{\circ}$ (2), $75^{\circ}$ (3), $85^{\circ}$ (4) (Figure S26); ${ }^{1} \mathrm{H}-\mathrm{NMR}$ spectra of heterometallic complexes synthesized from 2 and $\mathrm{AgPF}_{6}(4), \mathrm{AgNO}_{3}(7)$ and $\mathrm{AgOTf}(\mathbf{8})$ in acetone-d $d_{6}$ (Figure S27); ${ }^{19}$ F-NMR spectra (perhalogenated aromatic part) of heterometallic complexes synthesized from 1 and $\mathrm{AgPF}_{6}(3), \mathrm{AgNO}_{3}(5)$ and $\mathrm{AgOTf}(6)$ in acetone- $d_{6}$ (Figure S28); ${ }^{31} \mathrm{P}-\mathrm{NMR}$ spectra of heterometallic complexes (phosphane region) synthesized from 1 and $\operatorname{AgPF}_{6}(\mathbf{3}), \mathrm{AgNO}_{3}(\mathbf{5})$ and $\operatorname{AgOTf}(\mathbf{6})$ in acetone-d $d_{6}$ (Figure S29); ${ }^{31} \mathrm{P}-\mathrm{NMR}$ spectra of heterometallic complexes (phosphane region) synthesized from 2 and $\mathrm{AgPF}_{6}$ (4) $\mathrm{AgNO}_{3}$ (7) and AgOTf (8) in acetone- $d_{6}$ (Figure S30); ${ }^{19} \mathrm{~F}-\mathrm{NMR}$ spectra of heterometallic complexes synthesized from 2 and $\mathrm{AgPF}_{6}(\mathbf{4}), \mathrm{AgNO}_{3}(7)$ and $\operatorname{AgOTf}_{(8)}$ in acetone- $d_{6}$ (Figure S31); Normalized emission spectra of $\mathbf{1}$ and heterometallic complexes with nitrate, triflate and hexafluorophosphate silver salts in solid state. $\lambda_{\mathrm{exc}}=$ $375 \mathrm{~nm}$ (Figure S32); Absorption spectra of 1.AgNO3 at different concentrations in water. Inset: Representation of absorption at $254 \mathrm{~nm}$ versus concentration (Figure S33); Emission spectra of $\mathbf{1} \cdot \mathrm{AgNO} 3$ at different concentrations in water. Inset: Representation of emission at $475 \mathrm{~nm}$ versus concentration. $\lambda_{\mathrm{exc}}=350 \mathrm{~nm}$ (Figure S34); Absorption spectra of 1.AgOTf at different concentrations in water. Inset: Representation of absorption at $254 \mathrm{~nm}$ versus concentration (Figure S35); Emission spectra of 1.AgOTf at different concentrations in water. Inset: Representation of emission at $475 \mathrm{~nm}$ versus concentration. $\lambda_{\text {exc }}=325 \mathrm{~nm}$ (Figure S36); Absorption spectra of $\mathbf{2} \cdot \mathrm{AgNO}_{3}$ at different concentrations in water. Inset: Representation of absorption at $254 \mathrm{~nm}$ versus concentration (Figure S37); Emission spectra of $\mathbf{2} \cdot \mathrm{AgNO}_{3}$ at different concentrations in water. Inset: Representation of emission at $398 \mathrm{~nm}$ versus concentration (Figure S38); Absorption spectra of $\mathbf{2} \cdot \mathrm{AgOTf}$ at different concentrations in water. Inset: Representation of absorption at $255 \mathrm{~nm}$ versus concentration (Figure S39); Emission spectra of $\mathbf{2} \cdot \mathrm{AgOTf}$ at different concentrations in water. Inset: Representation of emission at $550 \mathrm{~nm}$ versus concentration (Figure S40); Optical microscopy image of the dried samples of aqueous solutions of 5-8 at $1 \cdot 10^{-4} \mathrm{M}$ concentration (Figure S41); Selected Bond Lengths $(\AA)$ and Angles (deg) for $\mathbf{1}$ and $\mathbf{2} \cdot 0.5 \mathrm{H}_{2} \mathrm{O}$ (Table S1); Crystal data and structure refinement for 1 and $2 \cdot 0.5 \mathrm{H}_{2} \mathrm{O}$ (Table S2); Hydrogen bonds for complex 2.0.5 $\mathrm{H}_{2} \mathrm{O}\left[\AA\right.$ and $^{\circ}$ ] (Table S3); Selected Bond Lengths ( $⿱$ ) and Angles (deg) for 4. $\mathrm{NCMe} \cdot \mathrm{Me}_{2} \mathrm{CO} \cdot 0.5 \mathrm{H}_{2} \mathrm{O}$ (Table $\mathrm{S} 4$ ); Crystal data and structure refinement for 
4. $\mathrm{NCMe} \cdot \mathrm{Me}_{2} \mathrm{CO} \cdot 0.5 \mathrm{H}_{2} \mathrm{O} \quad$ (Table S5); Hydrogen bonds for complex 4. $\mathrm{NCMe} \cdot \mathrm{Me}_{2} \mathrm{CO} \cdot 0.5 \mathrm{H}_{2} \mathrm{O}\left[\AA\right.$ and $\left.^{\circ}\right]$ (Table S6). 


\section{References}

${ }^{1}$ Gold-Metal Interactions and Applications; Laguna, A., Ed.; Wiley-VCH: Weinheim, Germany, 2008.

${ }^{2}$ Pyykkö, P. Relativity, Gold, Closed-Shell Interactions, and $\mathrm{CsAu} \cdot \mathrm{NH}_{3}$. Angew. Chem., Int. Ed. 2002, 41, 3573.

${ }^{3}$ Fernández, E. J.; Laguna, A.; López-de-Luzuriaga, J. M.; Monge, M.; Montiel, M.; Olmos, M. E.; Rodríguez-Castillo, M. Pyridine gold complexes. an emerging class of luminescent materials. Gold Bull. 2007, 40, 172.

${ }^{4}$ Calhorda, M. J.; Crespo, O.; Gimeno, M. C.; Jones, P. G.; Laguna, A.; López-deLuzuriaga, J. M.; Perez, J. L.; Ramón, M. A.; Veiros, L. F. Synthesis, Structure, Luminescence, and Theoretical Studies of Tetranuclear Gold Clusters with Phosphinocarborane Ligands. Inorg. Chem. 2000, 39, 4280.

5 Roundhill, D. M.; Fackler, J. P., Jr. Optoelectronic Properties of Inorganic Compounds; Plenum: New York, 1999.

${ }^{6}$ Lima, J.C.; Rodríguez, L. Applications of gold(I) alkynyl systems: a growing field to explore. Chem. Soc. Rev. 2011, 40, 5442.

${ }^{7}$ Schmidbaur, H.; Schier, A. Aurophilic interactions as a subject of current research: an up-date. Chem. Soc. Rev. 2012, 41, 370.

${ }^{8}$ López-de-Luzuriaga, J.M.; Monge, M.; Olmos, M.E.; Pascual, D. Study of the Nature of Closed-Shell $\mathrm{Hg}^{\mathrm{II}} \cdots \mathrm{M}^{\mathrm{I}}(\mathrm{M}=\mathrm{Cu}, \mathrm{Ag}$, Au) Interactions. Organometallics. 2015, 34, 3029 .

${ }^{9}$ Zhang, Q.-W.; Li, D.; Li, X.; White, P.B.; Mecinović, J.; Ma, X.; Ågren, H.; Nolte, R.J.M.; Tian, H. Multicolor Photoluminescence Including White-Light Emission by a Single Host-Guest Complex. J. Am. Chem. Soc. 2016, 138, 13541.

${ }^{10}$ Woodall, C.H.; Beavers, C.M.; Christensen, J.; Hatcher, L.E.; Intissar, M.; Parlett, A.; Teat, S.J.; Reber, C.; Raithby, P.R. Hingeless negative linear compression in the mechanochromic gold complex [(C6F5Au)2( $\mu$-1,4-diisocyanobenzene)]. Angew. Chem. Int. Ed. 2013, 52, 9691.

${ }^{11}$ Aguiló, E.; Gavara, R.; Baucells, C.; Guitart, M.; Lima, J.C.; Llorca, J.; Rodríguez, L. Tuning supramolecular aurophilic structures: the effect of counterion, positive charge and solvent. Dalton Trans. 2016, 45, 7328. 
12 Arcau, J.; Andermark, V.; Aguiló, E.; Gandioso, A.; Moro, A.; Cetina, M.; Lima, J.C.; Rissanen, K.; Ott, I.; Rodríguez, L. Luminescent alkynyl-gold(I) coumarin derivatives and their biological activity Dalton Trans., 2014, 43, 4426.

${ }^{13}$ Gavara, R.; Llorca, J.; Lima, J.C.; Rodríguez, L. A luminescent hydrogel based on a new $\mathrm{Au}(\mathrm{I})$ complex. Chem. Commun., 2013, 49, 72.

14 Aguiló, E.; Gavara, R.; Lima, J.C.; Llorca, J.; Rodríguez, L. From Au(I) organometallic hydrogels to well-defined $\mathrm{Au}(0)$ nanoparticles. J. Mater. Chem. C. 2013, 1,5538 .

${ }^{15}$ Moro, A.J.; Rome, B.; Aguiló, E.; Arcau, J.; Puttreddy, R.; Rissanen, K.; Lima, J.C.; Rodríguez, L. A coumarin based gold(I)-alkynyl complex: a new class of supramolecular hydrogelators. Org. Biomol. Chem. 2015, 13, 2026.

16 Gavara, R.; Aguiló, E.; Fonseca-Guerra, C.; Rodríguez, L.; Lima, J.C. Thermodynamic Aspects of Aurophilic Hydrogelators. Inorg. Chem. 2015, 54, 5195.

${ }^{17}$ Liang, J.; Chen, Z.; Yin, J.; Yu, G.-A.; Liu, S.H. Aggregation-induced emission (AIE) behavior and thermochromic luminescence properties of a new gold(I) complex. Chem. Commun. 2013, 49, 3567.

${ }^{18}$ Ito, H.; Saito, T.; Oshima, N.; Kitamura, N.; Ishizaka, S.; Hinatsu, Y.; Wakeshima, M.; Kato, M.; Tsuge, K.; Sawamura, M. Reversible Mechanochromic Luminescence of $\left[\left(\mathrm{C}_{6} \mathrm{~F}_{5} \mathrm{Au}\right)_{2}(\mu-1,4-\right.$ Diisocyanobenzene $\left.)\right]$. J. Am. Chem. Soc. 2008, 130, 10044.

${ }^{19}$ Ferrer, M.; Mounir, M.; Rodríguez, L.; Rossell, O.; Coco, S.; Gómez-Sal, P.; Martín, A. Effect of the organic fragment on the mesogenic properties of a series of organogold(I) isocyanide complexes. X-ray Crystal structure of $\left[\mathrm{Au}\left(\mathrm{CCC}_{5} \mathrm{H}_{4} \mathrm{~N}\right)\left(\mathrm{CNC}_{6} \mathrm{H}_{4} \mathrm{O}(\mathrm{O}) \mathrm{CC}_{6} \mathrm{H}_{4} \mathrm{OC}_{10} \mathrm{H}_{21}\right)\right]$. J. Organomet. Chem. 2005, 690, 2200. ${ }^{20}$ Pinto, A.; Svahn, N.; Lima, J.C.; Rodríguez, L. Aggregation Induced Emission of Gold(I) complexes in water or water mixtures. Dalton Trans. 2017 DOI: 10.1039/C7DT02349A.

${ }^{21}$ Siele, V. I. Some reactions of 1,3,5-Triaza-7-phosphaadamantane and its 7-Oxide. $J$. Heterocycl. Chem. 1977, 14, 337.

${ }^{22}$ Mohr, F.; Cerrada, E.; Laguna, M. Organometallic Gold(I) and Gold(III) Complexes Containing 1,3,5-Triaza-7-phosphaadamantane (TPA): Examples of Water-Soluble Organometallic Gold Compounds. Organometallics 2006, 25, 644.

23 Vergara, E.; Cerrada, E.; Casini, A.; Zava, O.; Laguna, M.; Dyson, P.J. Antiproliferative Activity of Gold(I) Alkyne Complexes Containing Water-Soluble Phosphane Ligands. Organometallics, 2010, 29, 2596. 
Assefa, Z.; Omary, M.A.; McBurnett, B.G.; Mohamed, A.A.; Patterson, H.H.; Staples, R.J.; Fackler, J.P. Syntheses, Structure, and Photoluminescence Properties of the 1-Dimensional Chain Compounds $\left[(\mathrm{TPA})_{2} \mathrm{Au}\right]\left[\mathrm{Au}(\mathrm{CN})_{2}\right]$ and $(\mathrm{TPA}) \mathrm{AuCl}(\mathrm{TPA}=$ 1,3,5-Triaza-7-phosphaadamantane). Inorg. Chem. 2002, 41, 6274.

${ }^{25}$ Mohr, F.; Cerrada, E.; Laguna, M. Organometallic Gold(I) and Gold(III) Complexes Containing 1,3,5-Triaza-7-phosphaadamantane (TPA): Examples of Water-Soluble Organometallic Gold Compounds. Organometallics 2006, 25, 644.

26 Forward, J.M.; Fackler, Jr., J.P.; Staples, R.J. Synthesis and Structural Characterization of the Luminescent Gold(I) Complex [(MeTPA $\left.)_{3} A u I\right] I_{3}$. Use of $\mathrm{NaBPh}_{4}$ as a Phenyl-Transfer Reagent To Form [(MeTPA)AuPh] $\left(\mathrm{BPh}_{4}\right)$ and (TPA)AuPh. Organometallics 1996, 14, 4194.

${ }^{27}$ Overton, A.T.; López-de-Luzuriaga, J.M.; Olmos, M.E.; Mohamed, A.A. Oxidative Rearrangement in Gold Organometallics. Organometallics, 2012, 31, 3460.

${ }^{28}$ Bojan, V.R.; López-de-Luzuriaga, J.M.; Manso, E.; Monge, M.; Olmos, M.E. MetalInduced Phosphorescence in (Pentafluorophenyl)gold(III) Complexes. Organometallics, 2011, 30, 4486.

${ }^{29}$ Echeverría, R.; López-de-Luzuriaga, J.M.; Monge, M.; Moreno, S.; Olmos, M.E. New Insights into the $\mathrm{Au}(\mathrm{I}) \cdots \mathrm{Pb}(\mathrm{II})$ Closed-Shell Interaction: Tuning of the Emissive Properties with the Intermetallic Distance. Inorg. Chem. 2016, 55, 10523.

${ }^{30}$ Gimeno, M.C.; López-de-Luzuriaga, J.M.; Manso, E.; Monge, M.; Olmos, M.E.; Rodríguez-Castillo, M.; Tena, M.T.; Day, D.P.; Lawrence, E.J.; Wildgoose, G.G. Synthesis, Photochemical, and Redox Properties of Gold(I) and Gold(III) Pincer Complexes Incorporating a 2,2':6',2"-Terpyridine Ligand Framework. Inorg. Chem. 2015, 54, 10667.

${ }^{31}$ Bojan, R.V.; Czerwieniec, R.; Laguna, A.; Lasanta, T.; López-de-Luzuriaga, J.M.; Monge, M.; Olmos, M.E.; Yersin, H. Luminescent gold-silver complexes derived from neutral bis(perfluoroaryl)diphosphine gold(I) precursors. Dalton Trans., 2013, 42, 4267. ${ }^{32}$ Fernández, E.J.; Laguna, A.; López-de-Luzuriaga, J.M.; Montiel, M.; Olmos, M.E.; Pérez, J.; Puelles, R.C. Mesitylgold(I) and Silver(I) Perfluorocarboxylates as Precursors of Supramolecular Au/Ag Systems. Organometallics, 2006, 25, 4307.

${ }^{33}$ Fernández, E.J.; Jones, P.G.; Laguna, A.; López-de- Luzuriaga, J. M.; Monge, M.; Olmos, M.E.; Puelles, R.C. Perhalophenyl(tetrahydrothiophene)gold(I) Complexes as Lewis Bases in Acid-Base Reactions with Silver Trifluoroacetate. Organometallics, 2007, 26, 5931. 
${ }^{34}$ Fernández, E.J.; Hardacre, C.; Laguna, A.; Lagunas, M.C.; López-de-Luzuriaga, J.M.; Monge, M.; Montiel, M.; Olmos, M.E.; Puelles, R.C.; Sánchez-Forcada, E. Multiple Evidence for Gold(I) $\cdots$ Silver(I) Interactions in Solution. Chem. Eur. J., 2009, 16, 6222. ${ }^{35}$ Rodríguez, L.; Ferrer, M. ; Crehuet, R.; Anglada, J.; Lima, J.C. Correlation between Photophysical Parameters and Gold-Gold Distances in Gold(I) (4-Pyridyl)ethynyl Complexes. Inorg. Chem. 2012, 51, 7636.

${ }^{36}$ Ni, W.-X.; Qiu, Y.-M.; Li, M.; Zheng, J.; Wai-Yin Sun, R.; Zhan, S.-Z.; Weng Ng, S. Li, D. Metallophilicity-Driven Dynamic Aggregation of a Phosphorescent Gold(I)Silver(I) Cluster Prepared by Solution-Based and Mechanochemical Approaches. J. Am. Chem. Soc. 2014, 136, 9532.

${ }^{37}$ Gavara, R.; Aguiló, E.; Schur, J.; Llorca, J.; Ott, I.; Rodríguez, L. Study of the effect of the chromophore and nuclearity on the aggregation and potential biological activity of gold(I) alkynyl complexes. Inorg. Chim. Acta 2016, 446, 189.

${ }^{38}$ Gavara, R.; Lima, J.C.; Rodríguez, L. Effect of solvent polarity on the spectroscopic properties of an alkynyl gold(I) gelator. The particular case of water. Photochem. Photobiol. Sci., 2016, 15, 635.

39 Burguete, M. I.; Galindo, F.; Gavara, R.; Izquierdo, M. A.; Lima, J. C.; V. Luis, S. V.; Parola A. J.; Pina, F. Use of Fluorescence Spectroscopy To Study Polymeric Materials with Porous Structure Based on Imprinting by Self-Assembled Fibrillar Networks. Langmuir 2008, 24, 9795.

40 Rodríguez-Llansola, F.; Escuder, B.; Hamley, I.W.; Hayes, W.; Miravet, J.F. Structural and morphological studies of the dipeptide based L-Pro-L-Val organocatalytic gels and their rheological behaviour. Soft Matter 2012, 8, 8865

${ }^{41}$ Peng, C.; Guo, Y.; Turiv, T.; Jiang, M.; Wei, Q.-H.; Lavrentovich, O.D. Patterning of Lyotropic Chromonic Liquid Crystals by Photoalignment with Photonic Metamasks. Adv. Mater. 2017, 29, 1606112.

${ }^{42}$ Hsu, T.H.T.; Naidu, J.J.; Yang, B.J.; Jang, M.Y.; Lin, I.J.B. Self-Assembly of Silver(I) and Gold(I) N-Heterocyclic Carbene Complexes in Solid State, Mesophase, and Solution. Inorg. Chem. 2012, 51, 98.

${ }^{43}$ Usón, R.; Laguna, A.; Vicente, J. Preparation and properties of stable salts containing mono- or bis-(pentafluorophenyl)aurate(I) and mono-, tris-, or tetrakis(pentafluorophenyl)aurate(III) ions. J. Chem. Soc. Chem. Commun. 1976, 353. 
For Table of Contents Only

Different $\mathrm{Au} \cdots \mathrm{Ag}$ heterometallic complexes containing $\mathrm{C}_{6} \mathrm{~F}_{5}$ perhalogenated ligand and water soluble phosphanes (PTA and DAPTA) have been synthesized and their aggregation in water has been explored. The resulting supramolecular morphologies and their luminescence are observed to depend directly on the counterion of the silver salt. The use of PTA or DAPTA has also a key role on the establishment of weak intermolecular contacts. 